\title{
River-floodplain hydrology of an embanked lowland Chalk river and initial response to embankment removal
}

\author{
H.M. Clilverd ${ }^{1}$, J.R. Thompson ${ }^{1}$, C.M. Heppell ${ }^{2}$, C.D. Sayer ${ }^{1}$ and J.C. Axmacher ${ }^{1}$ \\ ${ }^{1}$ UCL Department of Geography, University College London, Pearson Building, Gower Street, London, WC1E 6BT, UK \\ h.clilverd@ucl.ac.uk \\ ${ }^{2}$ Department of Geography, Queen Mary University of London, Mile End Road, London, E1 4NS, UK
}

Received 30 August 2011; accepted 26 October 2012; open for discussion until 1 October 2013

Editor Z.W. Kundzewicz; Associate editor K. Heal

Citation Clilverd, H.M., Thompson, J.R., Heppell, C.M., Sayer, C.D., and Axmacher, J.C., 2013. River-floodplain hydrology of an embanked lowland Chalk river and initial response to embankment removal. Hydrological Sciences Journal, 58 (3), $627-650$.

\begin{abstract}
Rivers have been channelized, deepened and constrained by embankments for centuries to increase agricultural productivity and improve flood defences. This has decreased the hydrological connectivity between rivers and their floodplains. We quantified the hydrological regime of a wet grassland meadow prior to and after the removal of river embankments. River and groundwater chemistry were also monitored to examine hydrological controls on floodplain nutrient status. Prior to restoration, the highest river flows $\left(\sim 2 \mathrm{~m}^{3} \mathrm{~s}^{-1}\right)$ were retained by the embankments. Under these flow conditions the usual hydraulic gradient from the floodplain to the river was reversed so that subsurface flows were directed towards the floodplain. Groundwater was depleted in dissolved oxygen (mean: $0.6 \mathrm{mg} \mathrm{O}_{2} \mathrm{~L}^{-1}$ ) and nitrate (mean: $\left.0.5 \mathrm{mg} \mathrm{NO}_{3}^{-}-\mathrm{N} \mathrm{L}^{-1}\right)$ relative to river water (mean: $10.8 \mathrm{mg} \mathrm{O}$ $\mathrm{L}^{-1}$ and $6.2 \mathrm{mg} \mathrm{NO}_{3}^{-}-\mathrm{N} \mathrm{L}^{-1}$, respectively). Removal of the embankments has reduced the channel capacity by an average of $60 \%$. This has facilitated over-bank flow which is likely to favour conditions for improved flood storage and removal of river nutrients by floodplain sediments.
\end{abstract}

Key words river restoration; surface-subsurface connectivity; floodplain; Chalk; nitrogen

\begin{abstract}
Hydrologie du système rivière-lit majeur d'un cours d'eau endigué de plaine sur la craie et réponse initiale à la suppression des digues

Résumé Depuis des siècles, les cours d'eau ont été canalisés, sur-creusés, et endigués pour accroître la productivité agricole et améliorer la protection contre les crues. Il en a résulté une baisse de la connectivité hydrologique entre ces cours d'eau et leur lit majeur. Nous avons quantifié le régime hydrologique d'une prairie humide avant et après l'élimination de digues la séparant du cours d'eau adjacent. Les compositions chimiques du cours d'eau et de la nappe phréatique ont également été suivies afin de caractériser les interactions entre hydrologie et statut trophique du sol au niveau du lit majeur. Avant restauration, même les plus hauts débits $\left(\sim 2 \mathrm{~m}^{3} \mathrm{~s}^{-1}\right)$ étaient contenus dans le lit mineur par les digues. Dans ces conditions, le gradient hydraulique, dirigé habituellement du lit majeur vers le cours d'eau, s'inversait de telle manière que les écoulements souterrains s'effectuaient en direction du lit majeur. L'eau du sous-sol était plus pauvre en oxygène dissous (moyenne : $0,6 \mathrm{mg} \mathrm{O}_{2} \mathrm{~L}^{-1}$ ) et en nitrates (moyenne: $0,5 \mathrm{mg}$ $\mathrm{NO}_{3}^{-}-\mathrm{N} \mathrm{L}^{-1}$ ) que le cours d'eau (moyenne: $10,8 \mathrm{mg} \mathrm{O}_{2} \mathrm{~L}^{-1}$ et $6,2 \mathrm{mg} \mathrm{NO}_{3}^{-}-\mathrm{N} \mathrm{L}^{-1}$, respectivement). L'effacement des digues a réduit la capacité du lit mineur de $60 \%$ en moyenne. En facilitant les débordements, les travaux de restauration devraient conduire à un stockage plus important en période de crue et à une épuration de la rivière par stockage des éléments minéraux dans les alluvions.
\end{abstract}

Mots clefs restauration de rivière; connectivité entre surface et souterrain; plaine inondable; craie; azote

\section{INTRODUCTION}

Pristine river floodplain ecosystems are strongly influenced by disturbance associated with regular flooding events. They are characterised by high habitat heterogeneity, primary productivity and biodiversity (Grevilliot et al. 1998, Ward 1998, Gowing et al. 2002a, Woodcock et al. 2005). These conditions 
are driven by the strong hydrological connectivity between rivers and their floodplains, which facilitates the exchange of water, sediments, organic matter and nutrients that are fundamental in shaping floodplain structure and function (Triska et al. 1989, Ward and Stanford 1995, Poff et al. 1997, Grevilliot et al. 1998, Pringle 2003). In floodplain habitats, fluctuations in the soil water regime, associated with strong hydrological connectivity, are important for the creation of a dynamic and varying physical environment (Poff et al. 1997, Robertson et al. 2001). This, in turn, exerts a strong influence upon species composition, and the creation and maintenance of high biodiversity in pristine floodplain habitats (Ward 1998, Freeman et al. 2007). In addition to the ecological benefits of river-floodplain connections, the importance of floodplains for flood water storage and downstream flood peak attenuation has also been widely documented (DeLaney 1995, Bullock and Acreman 2003, Acreman et al. 2007, Hammersmark et al. 2008).

Floodplains are prominently positioned in the landscape between hillslopes and streams and river channels. They function as a collection point for groundwater, runoff from upland areas and river water. The degree of hydrological exchange between rivers and their floodplains varies widely and is a function of river-floodplain geomorphology, the magnitude-frequency characteristics of river discharge and sediment porosity (Triska et al. 1993, Boulton et al. 1998, Dahm et al. 1998). Subsurface exchange of water between a river and floodplain sediments is a relatively slow, but constant water-transfer mechanism (generally in the order of $\mathrm{cm} \mathrm{d}^{-1}$ ). Under baseflow conditions, groundwater flow is typically directed from the floodplain towards the channel, discharging water into the river. Conversely, during periods of peak river discharge when river stage is above the floodplain water table, flow is directed from the river onto the floodplain (Dingman 1994, Burt et al. 2002). Floodplain storage can therefore sustain stream baseflows in inter-storm periods and attenuate downstream flood peak discharges during storm events (Gregory et al. 1991, DeLaney 1995, Hill 2000).

In permeable floodplain sediments, the focus of this paper, subsurface flow of water from the river towards the floodplain is an important mechanism that can facilitate removal of river nutrients via plant assimilation and denitrification. Likewise, floodplain interception of shallow subsurface flow from hillslopes can be important for the removal of agricultural fertilisers in groundwater (Vidon and
Hill 2004, Billy et al. 2010). The importance of these subsurface pathways for denitrification may be increased in permeable alluvial sediments due to a favourable balance between residence time (resulting in depleted dissolved oxygen conditions) and supply of nitrate and organic matter that is required to drive the process. Optimum conditions for denitrification are often reported to occur 1-2 $\mathrm{m}$ from the river channel in the hyporheic zone (the saturated region beneath and adjacent to streams and rivers that contains both groundwater and surface water), where a strong redox gradient exists and nitrate-rich river water or groundwater intersects with alluvium that is rich in organic matter (Triska et al. 1989, Jones and Holmes 1996, Hedin et al. 1998, Burt et al. 1999).

Over-bank flow forms a second, more episodic mechanism which can often inundate large areas of a floodplain. It substantially enhances the intrusion of river water and accompanying particles into floodplain sediments and the underlying groundwater, so that, even in permeable floodplain settings, overbank flow may represent a major source of nutrients to floodplain plants and microbes. This can substantially increase the nutrient attenuation capacity of nitratelimited floodplains (Venterink et al. 2003, Forshay and Stanley 2005, Clilverd et al. 2008), as well as nitrate-loaded floodplains where flooding increases substrate availability for denitrifying bacteria (Baker and Vervier 2004). Over-bank flow not only leads to greater potential for nutrient removal from the river ecosystem, but is also important for flood water storage (Schade et al. 2002, Forshay and Stanley 2005, Hammersmark et al. 2008).

However, many floodplains, where over-bank flow was historically a regular occurrence, no longer flood frequently due to alteration of the natural flow regime. Regulation of rivers and streams over past centuries has had a lasting impact on the hydrological characteristics of floodplain ecosystems. Many rivers worldwide have been channelized, constrained by embankments, and deepened to aid agricultural production and protect agricultural and urban developments from flooding (Buijse et al. 2002, Tockner and Stanford 2002). This has disabled or restricted the over-bank flow mechanism, therefore severely limiting the hydrological connectivity between rivers and their floodplains. As a consequence, the transfer of water, sediment and nutrients to floodplains has been strongly impeded (Tockner et al. 1999, Wyżga 2001, Antheunisse et al. 2006). Floodplain restoration, through embankment removal and the reconfiguration of river channels, is now being increasingly employed 
to re-establish river-floodplain connections. The aims of these restoration works are often multifaceted and include enhanced floodplain biodiversity, improved nutrient-attenuation capacity and the provision of temporary storage of flood water (Muhar et al. 1995, Bernhardt et al. 2005). This study seeks to investigate the implications of river embankment removal on river-floodplain hydrological connectivity in a permeable, chalk setting.

Chalk aquifers are a major groundwater resource in northwestern Europe. They form an important contribution to river flow, maintaining stable flows of clear cool water in chalk rivers, even during extended periods of low rainfall (Sear et al. 1999, Allen et al. 2010). In pristine environments, these conditions are favourable for the development of diverse river macrophyte and faunal communities (Berrie
1992). However, chalk rivers are under increasing management pressures, including low-flow issues, due to enhanced groundwater abstraction. If river restoration is to be undertaken in these types of rivers, with the aim of enhancing river-floodplain interactions, then it is crucial that our understanding of hydrological connectivity is improved. This research studies river-floodplain hydrological connectivity both prior to and following a restoration scheme to remove river embankments on the River Glaven in north Norfolk, eastern England (Fig. 1). Two years of pre-restoration hydrological and chemical data, and 1.5 years of post-restoration hydrological data are reported here to address two research questions: (a) what is the hydrological and biogeochemical regime of an embanked-river floodplain; and (b) what is the initial response to embankment removal?

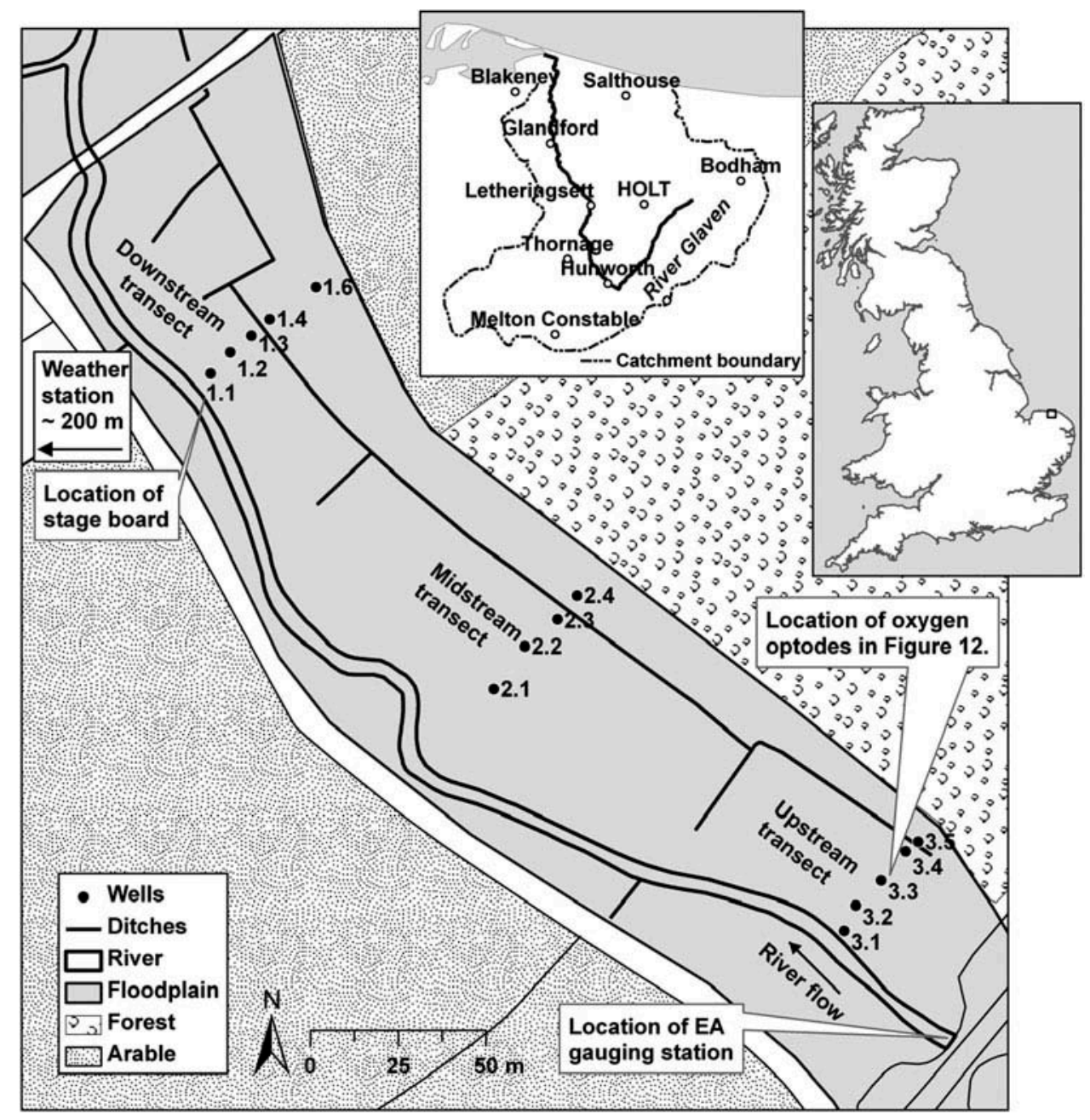

Fig. 1 The River Glaven restoration site at Hunworth, north Norfolk. The woodland and arable border along the northeast of the meadow delineates the base of a hillslope. Well 3.1 (upstream transect) was located on the river embankment; and Well 1.1 (downstream transect) behind the river embankment. The River Glaven catchment is shown inset, with the location of the study site at Hunworth. 


\section{METHODS}

\section{Study site}

The study was conducted at Hunworth Meadow on the River Glaven, north Norfolk, approximately $34 \mathrm{~km}$ northwest of Norwich $\left(52^{\circ} 52^{\prime} 55.53^{\prime \prime} \mathrm{N}, 01^{\circ} 03^{\prime}\right.$ $55.45^{\prime \prime} \mathrm{E}$; elevation approx. $20 \mathrm{~m}$ ). Average temperatures range from approx. $4^{\circ} \mathrm{C}$ in January to $17^{\circ} \mathrm{C}$ in July (date range 1950-2010, British Atmospheric Data Centre 2010). Mean annual precipitation is approx. $660 \mathrm{~mm}$ (date range 1950-2010), with highest rainfall typically occurring during the autumn and winter months (British Atmospheric Data Centre 2010). The River Glaven is $17 \mathrm{~km}$ in length, has a catchment area of $115 \mathrm{~km}^{2}$ and flows southwest from headwaters in Lower Bodham before taking an acute turn at Hunworth to continue northwards to Blakeney Point, where it discharges into the North Sea (Fig. 1) (Pawley 2008, Jacklin et al. 2010).
The Glaven Valley consists of Upper Cretaceous Chalk bedrock, which is overlain by chalk-rich stony, sandy, silty, boulder clay (Lowestoft Formation) up to $40 \mathrm{~m}$ thick. The Lowestoft Formation outcrops extensively throughout the Glaven catchment, but is overlain by Quaternary glaciogenic sand and gravel deposits (Briton's Lane Sand Gravel Member) at the study site (Fig. 2). Hillwash (also known as Head), a poorly sorted mixture of clay, sand, silt and gravel, typically occurs as a veneer less than one metre thick on the valley slopes, and up to several metres thick at the base of steep slopes. Alluvium along the floodplain of the River Glaven is estimated to be a maximum of $2 \mathrm{~m}$ thick, and consists predominantly of unconsolidated layers of sand and silt, but also includes sediments that range from clay to coarse gravel (Moorlock et al. 2002). For much of its length, the river is classified as a chalk stream (Pawley 2008). Rivers of this type typically flow

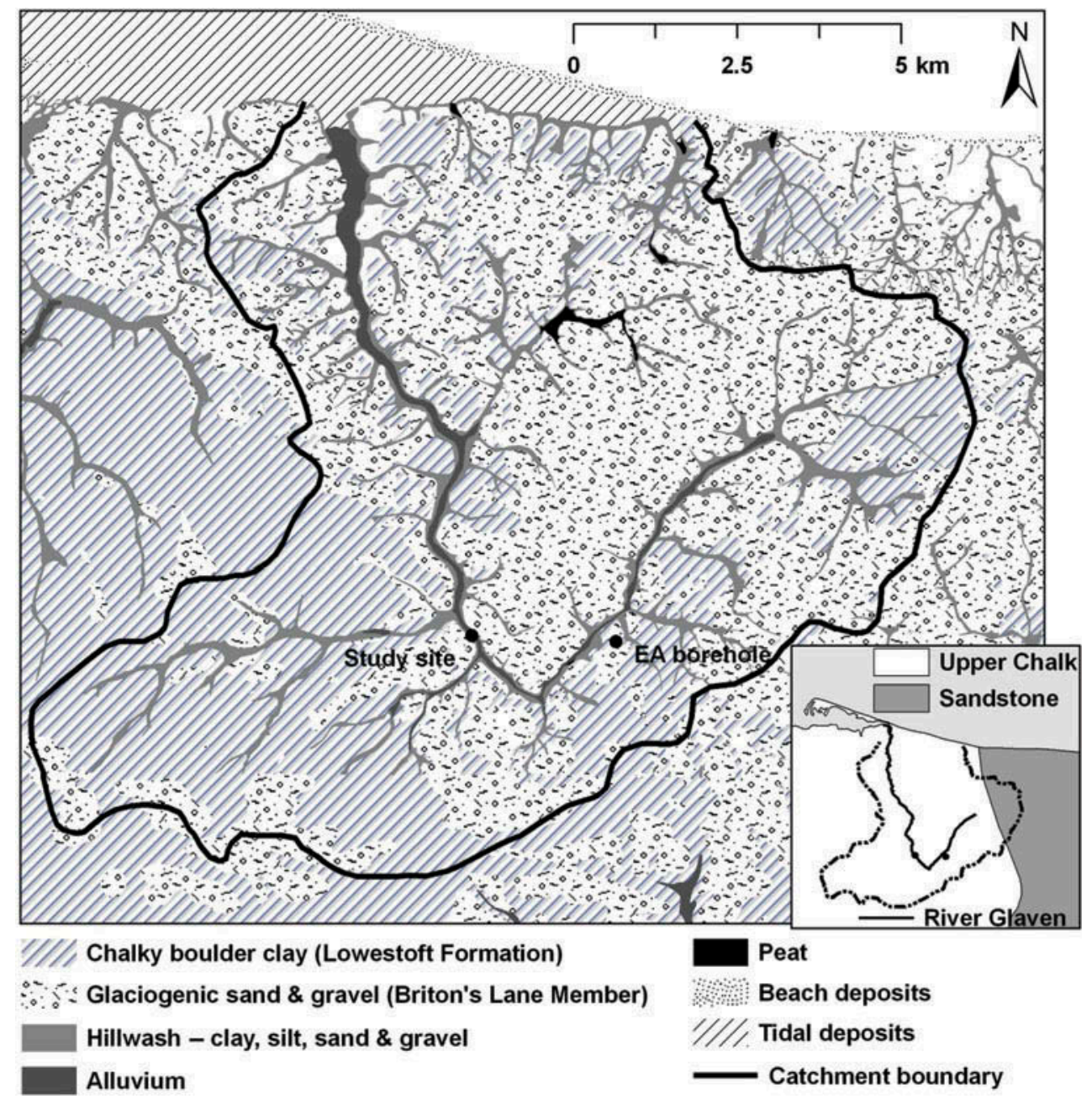

Fig. 2 Superficial geology of the River Glaven catchment, and regional bedrock geology (inset), based on British Geological Survey 1:50 000 map data. 
through mixed geologies for some of their length and, although local hydraulic features are important, they often maintain some of the characteristics of a groundwater-dominated chalk system, e.g. high baseflow index, dampened discharge fluctuations, stable substratum dominated by gravel and relatively high alkalinity (Sear et al. 1999).

The River Glaven flows through arable land, coniferous plantations and grazing meadows. Many reaches have been subject to extensive alterations which have involved the deepening and straightening of the channel and the construction of embankments. In addition, some floodplain areas have been drained and the natural vegetation has been widely cleared and transformed for agriculture. The natural flow of the river has also been interrupted or diverted by numerous weirs and mills. At Hunworth, the River Glaven was constrained by embankments along the entire length of the meadow study site. The meadow is approximately $400 \mathrm{~m}$ long, $40-80 \mathrm{~m}$ wide and has an area of approximately 3 ha. It is bounded to the northeast by an arable and woodland hillslope (Fig. 1). An agricultural drainage ditch, which was installed sometime between 1950 and 1980, runs parallel to the river along the floodplain. This ditch has become blocked towards the downstream end of the meadow in recent years, impairing the site's drainage. The management history of Hunworth Meadow is known from 1992 onwards. The meadow was intensively grazed by cattle until 2000, after which a less intense grazing regime, using mainly cattle with some sheep, has been established. Low levels of inorganic fertiliser were used until 1997, but since then Hunworth Meadow has not received any fertiliser application (Ross Haddow, Stody Estate, personal communication, 9 October 2012).

The River Glaven was straightened and its channel relocated at various times in the past, most recently around 1800 during the reconstruction of Thornage Mill, located approximately $100 \mathrm{~m}$ downstream from the study site. The river channel was subsequently deepened and embanked for flood defence purposes during the 1960s and 1970s. Restoration of the river was undertaken in March 2009 and involved the removal of approximately $1400 \mathrm{Mg}$ (megagrams) of soil from the embankments. The aim was to increase hydrological connectivity between the overdeepened, embanked river, and its long abandoned floodplain to improve flood storage, site drainage and ecological diversity within the floodplain (e.g. Leyer 2005, Acreman et al. 2007, Hammersmark et al. 2008).

\section{Study design}

Continuous observations of groundwater depth and river stage, measurements of groundwater chemistry and surveys of topography were collectively used to determine the hydrological impacts of river restoration. Groundwater wells were installed across the meadow in February 2007 in three transects approximately 33-39 m in length, each consisting of four or five wells (Fig. 1). Transects extended from the base of the arable and woodland hillslope to the river embankments and were aligned perpendicular to the river, i.e. parallel to the assumed main groundwater flow direction. The wells were installed at varying depths between 1.3 and $2.0 \mathrm{~m}$, due to the presence of alluvial gravels which proved difficult to penetrate with a hand auger. The wells were constructed from polypropylene pipe (inside diameter $=3.0 \mathrm{~cm}$ ), screened with $3 \mathrm{~mm}$ diameter holes and wrapped in geotextile cloth to prevent blockage by fine silts. The tops were covered with rubber caps between sampling dates. To prevent cattle trampling and damaging the wells, the top of the wells were approximately $1-2 \mathrm{~cm}$ below the soil surface, and covered with a protective concrete slab (approx. $30 \mathrm{~cm} \times 30 \mathrm{~cm}$ ).

\section{Hydrological monitoring}

To characterize fluctuations in groundwater elevation, Solinst combined pressure transducer-dataloggers (Levelogger Gold 3.0, Georgetown, ON, Canada) were installed in four wells at the upstream transect, one well at the midstream transect and five wells at the downstream transect. Groundwater elevation was recorded hourly from February 2007 to August 2010. Levelogger readings were checked during field visits with hand measurements of groundwater elevation along each well transect. The response of groundwater elevation relative to precipitation and river stage was determined using data from an automatic weather station (MiniMet SDL 5400, Skye, Powys, UK) that was located approximately $200 \mathrm{~m}$ from the site, and an Environment Agency (EA) gauging station (\#034052) located immediately upstream of Hunworth Meadows (Fig. 1). The weather station was installed in May 2007 and stored precipitation data at 30-min intervals.

Mean daily river stage and discharge data were available for the Hunworth gauging station for the period 2001-2010. However, there were some gaps in the record, because seasonal macrophyte growth in the channel downstream of the gauging station caused 
water to backup over the weir that impacted on the rating curve and reduced the accuracy of the data during these periods. This was manifested in a slow increase in baseflow through summer, despite low or no rainfall, upon which individual peaks associated with rainfall events were superimposed. Subsequently, this apparent elevated baseflow would decline during the autumn due to macrophyte dieback. The influence of the vegetation on discharge measurements was, in some cases, removed abruptly during flood events, possibly due to a devegetation of the river channel and relocation of sediment downstream. The influence of macrophyte growth on river discharge was easily identified in the discharge record when compared with precipitation data. The affected data are indicated in Fig. 3 within the current study and were excluded from quantitative analyses (baseflow index, flow duration).

The river baseflow index (BFI) was calculated for each full year of EA discharge data which included high-flow and low-flow years, using a baseflow separation program (BFI version 4.15) (Wahl and Wahl 2007) in order to characterise the regime of the river and, in particular, the likely influence of subsurface flows. The method employed follows the Institute of Hydrology (1980) baseflow separation procedure, in which the water year is divided into 5-day increments to identify minimum flow. The baseflow index is calculated as the ratio of baseflow volume to the total volume of streamflow. High BFI values indicate groundwater dominance, which is broadly represented by a stable flow regime (Sear et al. 1999). A detailed description of the BFI calculation is given by Gustard et al. (1992).

The contribution of groundwater to total river flow was also investigated using flow exceedence values for Q10 (a high-flow threshold that is equalled or exceeded for $10 \%$ of the flow record) and Q95 (a low-flow threshold equalled or exceeded for $95 \%$ of the flow record), which were determined from the river flow duration curve, derived using the complete record of stream discharge but excluding suspect data resulting from the impact of macrophyte growth on the rating curve. The Q95, expressed as the percentage of mean annual river flow, and the comparison of Q10 and Q95 provide a measure of the variability (i.e. flashiness) of the flow regime (Gustard et al. 1992, Marsh and Hannaford 2008).

Daily values of Penman-Monteith potential evapotranspiration (Monteith 1965) were computed from meteorological data (temperature, net radiation, humidity, wind speed) provided by the on-site weather station. These data were supplemented by a nearby
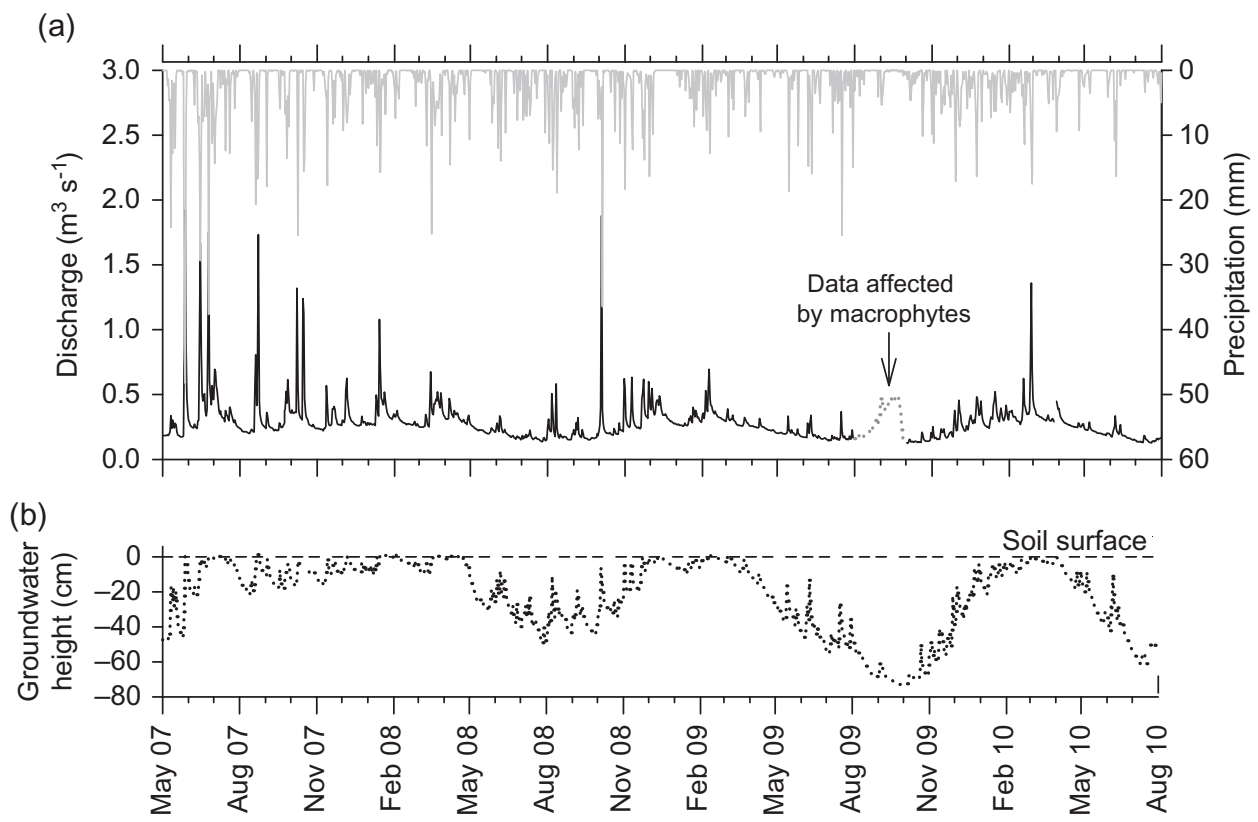

$$
\text { - River discharge } \quad \text {........ Groundwater _ Precipitation }
$$

Fig. 3 Temporal variation in (a) mean daily river discharge and total daily precipitation, and (b) representative mean daily groundwater height (downstream Well 1.6) for the four study years (2007-2010). The river discharge data affected by aquatic macrophyte growth (August-October 2009) are highlighted in (a). 
$(<10 \mathrm{~km})$ UK Met Office weather station (source ID: 24219, Mannington Hall). The reference formula for grasslands described by Allen (2000) was used, which assumes a constant grass height of $0.12 \mathrm{~m}$ throughout the year (see also Hough and Jones 1997), and a fixed surface resistance of $70 \mathrm{~s} \mathrm{~m}^{-1}$ with an albedo of 0.23 (Allen 2000).

\section{Physical soil properties}

Bulk density and porosity were calculated from the difference in the volume of saturated and dry soil (Elliot et al. 1999) collected using bulk density rings from the top 0-20 cm of soil. Organic matter content was subsequently analysed by the Loss on Ignition approach (Heiri et al. 2001). Soil particle size was determined with optical laser diffraction using an LS 13320 Coulter Counter Particle Size Analyser (Beckman Coulter Corp., Hialeah, FL, USA). Prior to analysis, the soil samples were treated with hydrogen peroxide to remove organic matter and subsequently with sodium hexametaphosphate $\left(\right.$ Calgon $\left.^{\mathrm{R}}\right)$ to disaggregate the soil particles (Chappell 1998).

\section{Hydraulic conductivity}

Hydraulic conductivity of the top $0.3-2 \mathrm{~m}$ of soil (assumed to be isotropic) was determined using piezometer slug tests $(n=9)$ following the approach of Surridge et al. (2005). Hydraulic conductivity of the organic topsoil was not measured because the slug tests were conducted during the summer when surface soils were dry. A Solinst 3.0 pressure transducer installed at the base of the piezometer recorded the recovery of the water table every 10 seconds after the slug; a sand ballast-filled PVC tube (outside diameter $=2.2 \mathrm{~cm}$ ), sealed at both ends with rubber bungs, was removed from the piezometer. Hydraulic conductivity was calculated from the recovery in hydraulic head assuming Darcian flow as:

$$
K=\frac{A}{F T}
$$

where $K$ is hydraulic conductivity $\left(\mathrm{cm} \mathrm{s}^{-1}\right) ; T$ is the basic hydrostatic time lag (s); $A$ is the inside cross-sectional area of the piezometer $(\mathrm{cm})$; and $F$ is the shape factor of the piezometer intake $(\mathrm{cm})$ (Hvorslev 1951, Baird et al. 2004, Surridge et al. 2005), calculated as:

$$
F=\frac{2.4 \pi l}{\log _{e}\left[\frac{1.2 l}{d}+\sqrt{1+\left(\frac{1.2 l}{d}\right)^{2}}\right]}
$$

where $d$ is the outside diameter of the intake $(\mathrm{cm})$; and $l$ is the length $(\mathrm{cm})$ (Brand and Premchitt 1980, Baird et al. 2004). The hydrostatic time lag $(T)$ was solved by fitting equation (3) to the measured head recovery data using a least-squares minimisation with $T$ as the fitted parameter:

$$
\frac{h}{h_{0}}=\mathrm{e}^{-t / T}
$$

where $h$ is the head difference at $t(\mathrm{~cm}) ; h_{0}$ is the initial head difference $(\mathrm{cm})$; and $t$ is time from the start of the test (s) (i.e. slug withdrawal) (Hvorslev 1951, Baird et al. 2004).

Subsurface flow rates assuming Darcian flow were calculated as:

$$
v=K \frac{\Delta h}{\Delta l} / n_{e}
$$

where $v$ is flow rate $\left(\mathrm{m} \mathrm{d}^{-1}\right) ; n_{e}$ is effective porosity; $\Delta h / \Delta l$ is the water table slope, which was obtained from hydraulic head measurements taken at each well along the transect; and $K$ is hydraulic conductivity $\left(\mathrm{m} \mathrm{d}^{-1}\right)$ (Domenico and Schwartz 1998). Mean values of $K$ and $\Delta h / \Delta l$ for each well transect were used in this calculation.

\section{River and groundwater chemistry}

River water and floodplain groundwater (top 1-2 m of soil) samples were taken bimonthly from April 2007 to June 2008 to examine spatial and temporal variations in subsurface chemistry. Water samples were collected using a point-source bailer and stored in pre-washed $250 \mathrm{~mL}$ polyethylene bottles. Before acquiring samples, the wells were purged to introduce fresh groundwater and the collection bottles were rinsed with well water. Samples were stored in a cooler until return to the laboratory, refrigerated and then filtered through $0.45-\mu \mathrm{m}$ filter paper. Any samples that could not be analysed within two days were frozen.

Dissolved oxygen (DO), $\mathrm{pH}$ and electrical conductivity were measured in the field at the time of water sampling using a YSI-555A DO meter (YSI Hydrodata Ltd., Letchworth, UK), a Mettler Toledo MP120 pH meter and a Mettler Toledo 
MC126 conductivity meter (Columbus, OH, USA), respectively. Measurements of DO in the soil profile were obtained at 30 -min intervals from two Aanderaa 4175 DO optodes (Bergen, Norway) connected to Campbell Scientific CR1000 dataloggers (Loughborough, UK). To evaluate temporal fluctuations in DO concentration within the rooting zone, the DO optodes were installed at the upstream well transect (Fig. 1) from January 2009 to August 2010. Initially, the optodes were installed in wells at 10and $30-\mathrm{cm}$ depths. However, in January 2010 the $30-\mathrm{cm}$ DO optode was moved from the well and buried directly in the soil at $10 \mathrm{~cm}$ below ground surface (b.g.s.). Although the optodes can remain in situ for more than one year without repeated calibration (Aanderaa 2006), the calibration was checked periodically using a zero-oxygen solution (sodium sulphite saturated in deionised water) and $100 \%$ saturated solution (deionised water bubbled with air).

In the laboratory, cations $\left(\mathrm{Ca}^{2+}, \mathrm{Mg}^{2+}, \mathrm{K}^{+}, \mathrm{Na}^{+}\right.$, $\left.\mathrm{NH}_{4}{ }^{+}\right)$and anions $\left(\mathrm{SO}_{4}{ }^{2-}, \mathrm{Cl}^{-}, \mathrm{NO}_{3}{ }^{-}, \mathrm{NO}_{2}{ }^{-}, \mathrm{PO}_{4}{ }^{3-}\right)$ were analysed by ion exchange chromatography (ICS2500, Dionex Corp., CA, USA). Dissolved organic carbon (DOC) and total dissolved nitrogen (TDN) were determined using a HiPerTOC carbon analyser plumbed to an HIPER5000 Total Nitrogen chemoluminescent detector (Thermo Electron Corp., Delft, The Netherlands). Prior to analysis of DOC, inorganic carbon was removed with the addition of $1 \mathrm{M}$ hydrochloric acid. Groundwater chemistry data of the chalk aquifer were obtained from an EA borehole within the Glaven catchment, located approximately $2 \mathrm{~km}$ from the study site at Edgefield ( $52^{\circ} 52^{\prime} 49.36^{\prime \prime}$ $\mathrm{N}, 01^{\circ} 05^{\prime} 52.91^{\prime \prime} \mathrm{E}$ ) (Fig. 1). The borehole was used to monitor water levels and chemistry in the chalk strata, and had a response zone of 38-41 m b.g.s. The data obtained from the EA borehole are assumed to be representative of the groundwater chemistry of the chalk underlying the study site. This is reasonable considering the close proximity of the EA borehole to the study site, and that the chalk is laterally continuous across the region (Fig. 2). Hence, throughout this paper, these borehole data refer to the regional groundwater.

\section{Soil chemistry}

To determine the soil fertility of Hunworth Meadow, floodplain soil samples were collected in April 2008 along the three well transects at depths of $10-20 \mathrm{~cm}(n=12)$. Soil samples were stored in a cooler with ice until return to the laboratory, where they were frozen pending analysis. In the laboratory, plant available nutrients were determined using standard extraction methods. For analysis of nitrate and ammonium, $100 \mathrm{ml}$ of $1 \mathrm{M}$ potassium chloride was added to $10 \mathrm{~g}$ of soil (Robertson et al. 1999). Potassium, calcium, magnesium, sodium, aluminium and iron were extracted using $100 \mathrm{ml}$ of $1 \mathrm{M}$ ammonium acetate solution added to $10 \mathrm{~g}$ soil (Hendershot et al. 2008). For analysis of total organic carbon (TOC), $100 \mathrm{ml}$ of deionised water was added to $10 \mathrm{~g}$ of soil (method amended from Robertson et al. 1999). Phosphate was analysed using the Olsen et al. (1954) sodium bicarbonate extraction method (Schoenau and O'Halloran 2008).

The percentage moisture content was determined for each soil sample by drying triplicate 10 -g subsamples of sieved field-moist soil at $105^{\circ} \mathrm{C}$ overnight (Robertson et al. 1999). This allowed the respective ion concentration for each extract to be corrected for dilution. Inorganic nitrogen species $\left(\mathrm{NO}_{3}{ }^{-}, \mathrm{NO}_{2}{ }^{-}\right.$ and $\mathrm{NH}_{4}{ }^{+}$) and phosphorus were analysed colorimetrically using an automated continuous flow analyser (SAN++, SKALAR, Delft, The Netherlands) following the standard San++ methods for preparation of reagents. Elemental metal analysis $\left(\mathrm{K}^{+}\right.$, $\mathrm{Ca}^{2+}, \mathrm{Mg}^{2+}, \mathrm{Na}^{+}, \mathrm{Al}^{-}, \mathrm{Fe}^{3+}$ ) was conducted using a Vista-PRO inductively coupled plasma optical emission spectrometer (ICP-OES) with a SPS3 autosampler (Varian, Eindhoven, The Netherlands). Total organic carbon was determined using a HiPerTOC carbon analyser (Thermo Electron Corp., Delft, The Netherlands). Exchangeable ions and TOC are expressed as element mass per dry mass of soil.

\section{River and floodplain topography}

Surface elevation of the meadow, river channel and, before their removal, the embankments were surveyed using a differential Global Positioning System (dGPS) (Leica Geosystems SR530 base station receiver and Series 1200 rover receiver, Milton Keynes, UK) in April 2008 prior to the restoration, and in July 2009 after the restoration. Each survey was conducted using the survey pole in static mode, which resulted in a 3D coordinate quality of $1-2 \mathrm{~cm}$. The meadow was surveyed at intervals of approximately $10 \mathrm{~m}$, whereas the river embankments and cross-sections were surveyed at a higher resolution using intervals of approximately $0.25-0.5 \mathrm{~m}$. River channel cross-sections were surveyed at 32 transects along the study reach prior to the restoration and at 23 transects after the restoration. Digital elevation 
models (DEMs) were created in ArcGIS using the kriging interpolation method, which estimates values from a statistically weighted average of nearby sample points (de Smith et al. 2007).

\section{Bankfull capacity and the effects of aquatic macrophytes on river flows}

The effects of embankment removal on the frequency of over-bank inundation were evaluated by estimating the change in bankfull capacity. A field-based method was used to relate bankfull elevation, measured before and after embankment removal using dGPS, to a stage board installed adjacent to the downstream well transect. Bankfull discharge was then predicted using a regression relationship between river stage in the Hunworth Meadows reach and discharge at the EA gauging station upstream of the meadows and approximately $0.3 \mathrm{~km}$ above the stage board (Figs 1 and 4). This method assumes that groundwater exchanges and runoff inputs do not significantly affect river discharge between the gauging station and stage board, which is reasonable considering their close proximity.

The regression relationship between river stage and discharge for spring/summer (AprilSeptember) follows a slightly lower trajectory than that for autumn/winter (October-March) $(p<0.05$, $F=35.41$ ) (Fig. 4). This can be attributed to the extensive growth of aquatic macrophytes, such as Apium nodiflorum, Phalaris arundinaceae and Rorippa nasturtium-aquaticum, within the channel during the growing season. Seasonal in-stream vegetation growth can have a significant effect on the fluvial dynamics of streams by modifying flow velocities and sedimentation rates (Champion and Tanner 2000, Clarke 2002), resulting in a reduction in channel capacity during spring and summer. However, the effects are often diminished at high flows due to compression of the macrophyte stems, or even devegetation, which can substantially reduce flooding potential (Chambers et al. 1991, Wilcock et al. 1999, Champion and Tanner 2000). For example, Chambers et al. (1991) reported that, in slow-flowing rivers in western Canada, macrophyte biomass decreased with increasing flow velocities over a mean range of $0.2-0.7 \mathrm{~m} \mathrm{~s}^{-1}$, with aquatic macrophytes typically absent at velocities above $1 \mathrm{~m} \mathrm{~s}^{-1}$.

Macrophyte abundance on the River Glaven was observed to be substantially lower during highflow summers (mean flow: $0.38 \mathrm{~m}^{3} \mathrm{~s}^{-1}$ ) compared with low-flow summers (mean flow: $0.19 \mathrm{~m}^{3}$ $\mathrm{s}^{-1}$ ), possibly due to devegetation at higher flows. As spring/summer river stage was only measured during periods of low river flows $\left(0.15-0.24 \mathrm{~m}^{3} \mathrm{~s}^{-1}\right)$ (Fig. 4), and the effects of macrophyte abundance is likely reduced during high flow conditions, the spring/summer regression equation was not used to determine bankfull capacity. Instead, bankfull capacity was calculated using the autumn/winter regression equation (Fig. 4), which encompasses river stage measurements for a wider range of flows $\left(0.25-1.9 \mathrm{~m}^{3} \mathrm{~s}^{-1}\right)$ during low macrophyte abundance.

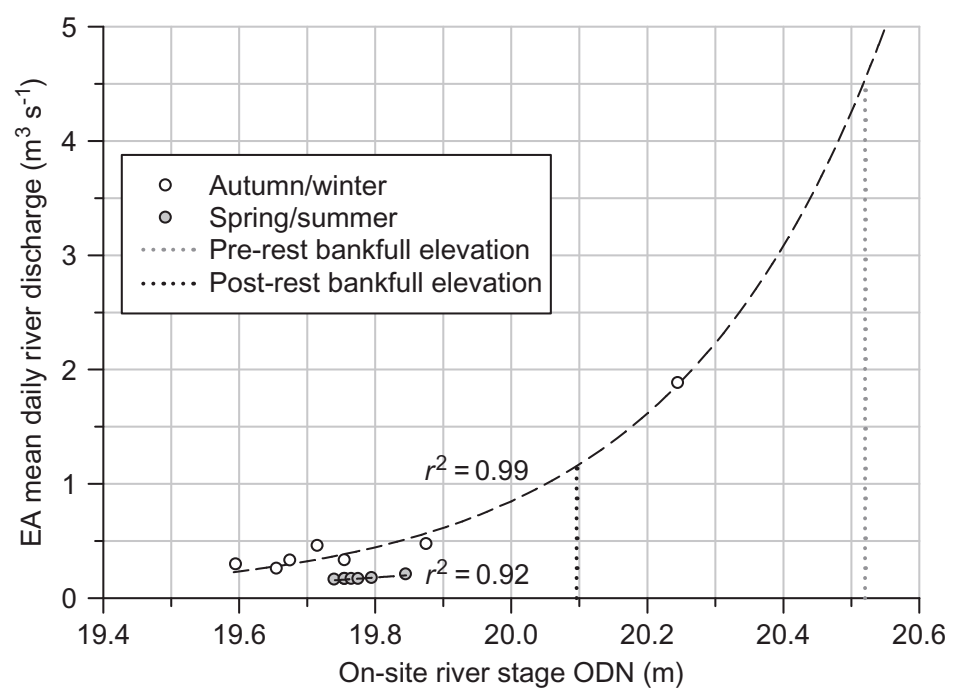

Fig. 4 Relationship between on-site river stage Ordnance Datum Newlyn (ODN) and mean daily river discharge used to determine bankfull capacity. Lines indicate statistically significant regression at $p<0.05, y_{\text {autumn} / \text { winter }}=7.6795 \times$ $10^{-29} \mathrm{e}^{3.2285 \mathrm{x}}, y_{\text {spring/summer }}=0.415 x-8.0379$. 
Bankfull discharge was also determined by a semi-empirical method using the Manning's equation for uniform flow:

$$
Q=\frac{1}{n} A R^{2 / 3} S^{1 / 3}
$$

where $Q$ is discharge $\left(\mathrm{m}^{3} \mathrm{~s}^{-1}\right) ; n$ is Manning's roughness coefficient; $A$ is bankfull cross-sectional area $\left(\mathrm{m}^{2}\right) ; R$ is hydraulic radius $(\mathrm{m})$; and $S$ is water surface slope $(\mathrm{m} / \mathrm{m})$ (Gordon et al. 2004). The value of Manning's $n$ was estimated using the Rosgen $(1996,2007)$ stream classification method. This required the following river morphology parameters: bankfull width-to-depth ratio, entrenchment ratio (flood-prone width at $2 \times$ bankfull depth/bankfull width), water surface slope and channel sinuosity, which were obtained from dGPS-derived river channel cross-sections and measurements of river channel length in ArcGIS. The River Glaven most closely fits Rosgen type C4 or C5 streams, which correspond to average bankfull Manning's $n$ values of approximately 0.04 and 0.056 , respectively (Rosgen 2007). A range of bankfull discharge estimates were calculated by holding all other terms constant and varying Manning's $n$ only between the two extremes of 0.04 and 0.056 . The Manning's bankfull estimates were subsequently compared with the bankfull stage-discharge estimates.

Recurrence interval (return period in years) of bankfull discharge was computed using flood peaks over threshold (POT) data, which were extracted from discharge data measured at the on-site EA gauging station from 2001 to 2010. Discharge data were arranged into water years beginning on 1 October, and the threshold value was set at $0.6 \mathrm{~m}^{3} \mathrm{~s}^{-1}$ so that, on average, five independent peaks per year were included in the series (Institute of Hydrology 1999, Cunderlik and Burn 2001). Aquatic macrophytes caused breaks in the river discharge record during some years; however, these years were included in the analysis where: (a) the gaps did not constitute a major portion of the record, and (b) precipitation data was available to confirm that large flood peaks were unlikely to have been missed.

\section{Statistical analysis}

Linear regression was used to evaluate relationships between river stage and mean daily river discharge for summer and winter periods. To test whether the summer and winter relationships differed, a full and reduced $F$-test comparison was used. One-way analysis of variance (ANOVA) in combination with Tukey's post hoc tests was used to test for significant $(p<0.05)$ differences in groundwater chemistry along well transects. To meet the required assumptions for statistical inference, all data were tested for linearity, constant variance and normality. Regressions and diagnostics were computed using SAS 9.2 statistical software for Windows (SAS Institute Inc., North Carolina, USA), and Sigma Plot 10.0 (Systat Software Inc., London, UK).

\section{RESULTS}

\section{River embankments}

Prior to the restoration, the River Glaven was constrained by embankments that ranged from 0.4 to $1.1 \mathrm{~m}$ (mean $=0.6 \mathrm{~m})$ above the meadow surface (Figs 5(a) and 6). The width and depth of the channel was fairly uniform along its length (Figs 5(a) and 6), indicative of a channelized and deepened river. Before restoration, channel depth (river bed to bank top) averaged $1.4 \pm 0.1 \mathrm{~m}$ along the study reach. After the removal of the embankments, channel depth was reduced by approximately $44 \%$, averaging $0.8 \pm$ $0.1 \mathrm{~m}$ along the study reach (Fig. 6), and riverside elevation approximated that of the adjacent floodplain (Fig. 5(b)). Embankment removal reduced channel cross-sectional area by approximately $51 \%$, from a mean of $6.5 \pm 0.6 \mathrm{~m}^{2}$ to $3.2 \pm 0.7 \mathrm{~m}^{2}$ along the study reach. Surface elevation on Hunworth Meadow is below river bankfull elevation and decreases with distance from the river, with the exception of a few local highs (Fig. 5(a) and (b)).

The restoration work was restricted to the removal of the river embankments and did not involve mechanical work in the channel. However, during the excavation of the embankments, some sediment was inadvertently dropped into the river and likely accumulated in the lower part of the study reach or further downstream. As a result, some reshaping and modification of the river bed geomorphology was evident immediately following the restoration (see river cross-section in Fig. 7).

\section{Climate and hydrology}

The mean River Glaven baseflow index (BFI) was 0.81 (range: $0.75-0.88$ ), and Q95 (expressed as \% of mean annual flow) was $51 \%$, indicating high groundwater contributions to discharge (Table 1). 

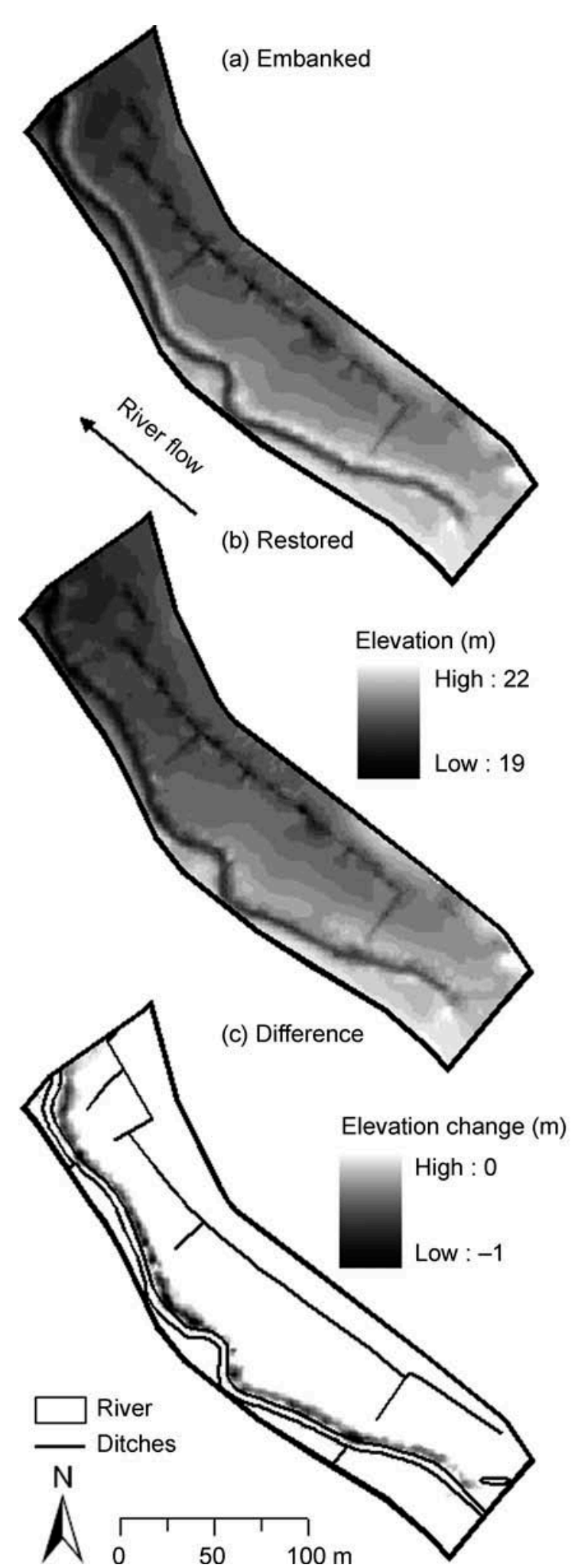

Fig. 5 Elevation of Hunworth Meadow study site showing (a) before and (b) after embankment removal, and (c) the difference in elevation. The DEMs were created using dGPS survey data collected in (a) June 2008 and (b) July 2009.
This is typical of permeable chalk streams, which average 0.83 BFI (range: 0.53-0.99) and $>30 \%$ Q95 (Gustard et al. 1992, Sear et al. 1999). River flow at the study site, in general, followed the characteristic annual hydrograph of a chalk stream, with increased discharge over the winter from early December until March. However, some of the highest recorded river flows occurred during the summer (Fig. 3(a)).

Precipitation had a distinct effect on river discharge, with flood peaks coinciding with precipitation events (Fig. 3(a)). River response to precipitation was rapid, typically within one day, although some events characterised by low intensity rainfall, prolonged over a few days, resulted in a muted stream flow response (Fig. 3(a)). Similarly, groundwater elevation on the floodplain responded rapidly ( $<1$ day) to precipitation and changing river levels, resulting in prolonged saturation of surface soils during winter/spring (November-April), with periodic saturation in summer/autumn (May-October) (Fig. 3(b)).

The period of observation prior to the restoration (2007-2008) was characterised by cooler, wetter spring/summers (Fig. 3(a) and Table 2). Summer (June-September) precipitation in 2007 and 2008 totalled 393 and $281 \mathrm{~mm}$, respectively and exceeded potential evapotranspiration, which totalled 248 and $262 \mathrm{~mm}$, respectively (Table 2). Summer precipitation in 2007 was highest of the four-year study period, which resulted in a shallow water table within $10 \mathrm{~cm}$ of the ground surface for much of the growing season between March and September (Fig. 3(b)). In comparison, water table elevations in 2008 were typically within $10 \mathrm{~cm}$ of the ground surface between March and May, due to a period of prolonged precipitation and high river discharge (Fig. 3(a) and (b)), and were slightly lower during the summer, averaging $33 \mathrm{~cm}$ below the ground surface (Fig. 3(a) and (b)).

Contrary to 2007 and 2008, the summers after the restoration were warm and dry, with total precipitation of 178 and $261 \mathrm{~mm}$ in 2009 and 2010, respectively. Furthermore, potential evapotranspiration was $10-19 \%$ higher, and exceeded total precipitation (Table 2). Collectively, this led to mean summer water table depths of 57 and $59 \mathrm{~cm}$ b.g.s. in 2009 and 2010, respectively (Fig. 3(b)). Summer river hydrographs were very similar in 2008, 2009 and 2010, all with a steady decline in discharge from May to August (Fig. 3(a)), and mean summer discharge of approx. $0.2 \mathrm{~m}^{3} \mathrm{~s}^{-1}$ (Table 2). However, whereas summer water table height differed by less than $4 \mathrm{~cm}$ on 


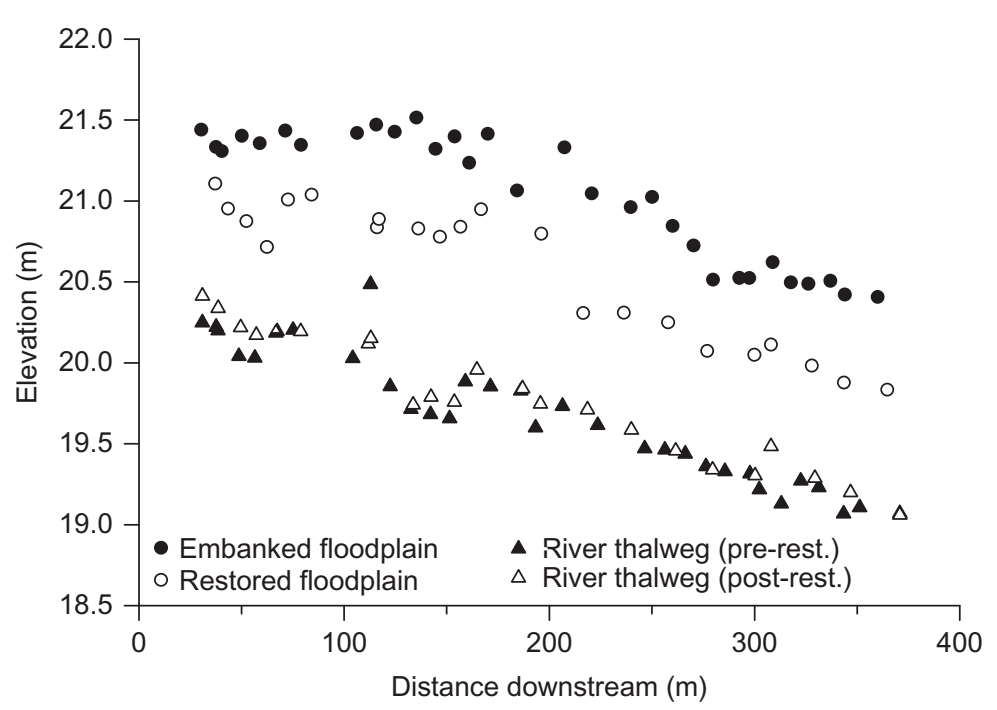

Fig. 6 Comparison of floodplain elevation adjacent to the river channel along the study reach before (embanked) and after (restored) embankment removal. The embanked floodplain data represent the highest point on the embankments, and the restored floodplain data represent the closest corresponding sample location after embankment removal. The river thalweg (pre- and post-restoration) is also plotted with distance downstream.

average between 2009 and 2010, water table height was on average 13-17 cm higher in 2008 compared to 2009 and 2010 (Fig. 3(b)).

Figure 7 shows groundwater levels on the floodplain during three different river flow conditions; high flow in autumn (October 2008), low flow in spring (March 2009) and low flow in summer (June 2008). The hydraulic gradient across the floodplain is relatively flat, averaging $6.1-9.4 \mathrm{~mm} \mathrm{~m}^{-1}$ (Table 3). Groundwater levels at the upstream transect indicate complex movements of groundwater, with shifts in hydraulic gradient observed between periods of different river flow. In general, at the upstream and midstream transect, groundwater levels decreased from the river towards the ditch, which was located at the lowest point of the floodplain (Fig. 7(a) and (b)). This was most apparent at the midstream well transect, where the river thalweg was above the ditch thalweg (Fig. 7(b)). Convergence of floodplain and hillslope flowpaths in the region of the ditch would explain the saturation of surface soils in this area of the floodplain. Conversely, at the downstream transect, where the topography flattens, groundwater levels tended to flow from the base of the hillslope towards the river (Fig. 7(c)).

Groundwater levels measured in wells next to the river (wells 3.1 and 1.1) were not always lower than river stage, indicating temporal changes in hydraulic gradient (Fig. 7(a) and (c)). During peak discharge conditions, river stage was above the water table in the floodplain and flow was directed away from the river and into the floodplain, creating a bank storage ridge (Figs 7(c) and 8). A streamward hydraulic gradient was re-established after the flood peak had passed (Fig. 8(c)). During low river stage in winter, groundwater levels on the floodplain were above that of the river (Fig. 7(a) and (b)). Conversely, during dry summers, when groundwater levels were typically low in the soil profile, river stage was often slightly above groundwater levels (Fig. 7).

\section{Soil physical and chemical properties}

Hunworth Meadow soils are predominantly sandy loams and slightly acidic (mean pH: 6.3-6.5). Soils were high in calcium, with an average of $1.7-2.7 \mathrm{mg}$ $\mathrm{Ca}^{2+} \mathrm{g}^{-1}$ (Table 4), and moderately fertile, with Olsen $\mathrm{P}$ concentrations of $6.2-9.5 \mathrm{mg} \mathrm{P} \mathrm{kg}{ }^{-1}$ on average, and mean plant available potassium concentrations of $1.0-2.8 \mathrm{mg} \mathrm{K}^{+} \mathrm{g}^{-1}$ (Table 4). Plant available ammonium concentration (average: $12.8-32.3 \mathrm{mg}$ $\mathrm{NH}_{4}{ }^{+}-\mathrm{N} \mathrm{kg}^{-1}$ ) was $11-26$ times greater than nitrate concentration (average: 0.5-3.0 mg NO${ }_{3}^{-}-\mathrm{N} \mathrm{kg}^{-1}$ ) (Table 4).

Topsoil (approx. 0-30 cm) on the meadow was moderately organic (range: $13-35 \%$ organic matter content; Table 4), with the highest organic matter content recorded in the wetter parts of the meadow. The sandy loam soils were underlain by alluvial gravels at depths of $0.8-2 \mathrm{~m}$. The majority of hydraulic conductivity measurements ranged between 0.98 and $7.72 \mathrm{~cm} \mathrm{~d}^{-1}$. However, due to 

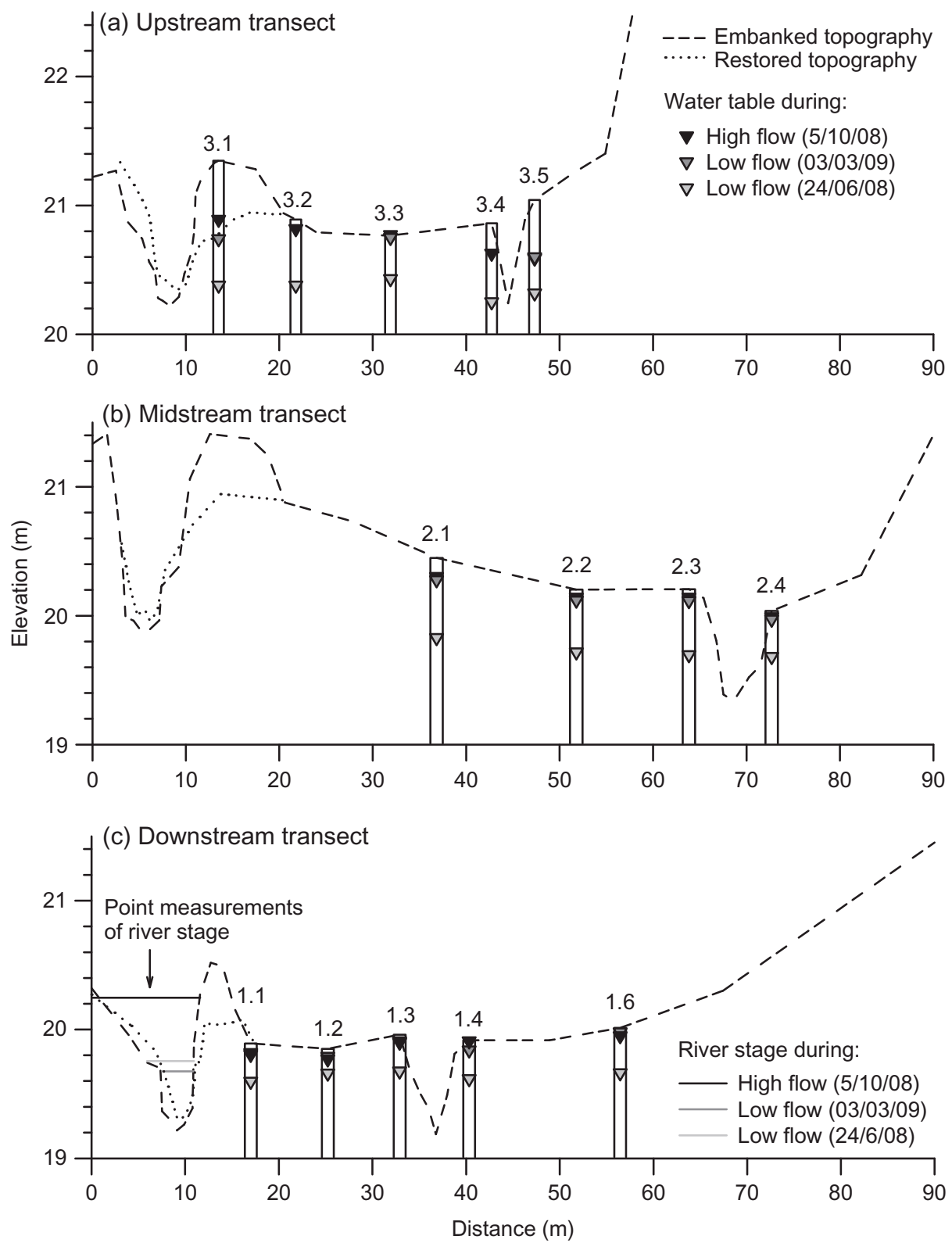

Fig. 7 Cross-sections of the meadow and river channel before (embanked) and after (restored) embankment removal. Typical mean well water levels are shown along the three transects in relation to low and high river stage. River stage measurements at the downstream transect are single point measurements.

Table 1 Mean annual river flow (range), Q10, Q95, and Q95 (as \% of mean annual flow) using river discharge data from 2001-2010. Mean baseflow index (BFI) (range) using continuous river discharge data for 2007, 2008, and 2010.

\begin{tabular}{|c|c|c|c|c|c|c|}
\hline \multicolumn{2}{|c|}{ Mean annual river discharge } & \multicolumn{2}{|c|}{ Mean baseflow index } & \multirow{2}{*}{$\begin{array}{l}\mathrm{Q} 10 \\
\left(\mathrm{~m} \mathrm{~s}^{-1}\right)\end{array}$} & \multirow{2}{*}{$\begin{array}{l}\text { Q95 } \\
\left(\mathrm{m} \mathrm{s}^{-1}\right)\end{array}$} & \multirow{2}{*}{$\begin{array}{l}\text { Q95 } \\
\text { (as \% mean } \\
\text { annual flow) }\end{array}$} \\
\hline$\left(\mathrm{m}^{3} \mathrm{~s}^{-1}\right)$ & Range & BFI & Range & & & \\
\hline 0.28 & $0.1-3.1$ & 0.81 & $0.75-0.88$ & 0.42 & 0.14 & 51.06 \\
\hline
\end{tabular}


Table 2 Summer (June-September) mean ( $\pm 95 \%$ confidence interval) air temperature, total precipitation, total potential evapotranspiration, and mean annual river discharge ( $\pm 95 \%$ confidence interval).

\begin{tabular}{lllll}
\hline Year & $\begin{array}{l}\text { Temperature } \\
\left({ }^{\circ} \mathrm{C}\right)\end{array}$ & $\begin{array}{l}\text { Precipitation } \\
(\mathrm{mm})\end{array}$ & $\begin{array}{l}\text { Evapotranspiration } \\
(\mathrm{mm})\end{array}$ & $\begin{array}{l}\text { River discharge } \\
\left(\mathrm{m}^{3} \mathrm{~s}^{-1}\right)\end{array}$ \\
\hline 2007 & $15.1 \pm 0.3$ & 393 & 248 & $0.38 \pm 0.05$ \\
2008 & $15.3 \pm 0.5$ & 281 & 262 & $0.19 \pm 0.01$ \\
2009 & $15.6 \pm 0.4$ & 178 & 286 & $0.24 \pm 0.01^{*}$ \\
2010 & $15.7 \pm 0.5$ & 261 & 295 & $0.19 \pm 0.01$ \\
\hline
\end{tabular}

Note: $* 2009$ mean river discharge is for 303 days.

Table 3 Hydraulic gradient, hydraulic conductivity and groundwater flow rate (mean $\pm 95 \%$ confidence interval) for the upstream, midstream and downstream well transects.

\begin{tabular}{llll}
\hline Transect & $\begin{array}{l}\text { Hydraulic gradient } \\
(\delta h / \delta l)\end{array}$ & $\begin{array}{l}\text { Hydraulic conductivity } \\
\left(\mathrm{cm} \mathrm{d}^{-1}\right)\end{array}$ & $\begin{array}{l}\text { Groundwater flow rate } \\
\left(\mathrm{cm} \mathrm{d}^{-1}\right)\end{array}$ \\
\hline Upstream & $0.0094 \pm 0.0033$ & $17.87 \pm 28.17(n=4)$ & $0.29 \pm 0.06$ \\
Midstream & $0.0067 \pm 0.0042$ & $3.04(n=1)$ & $0.03 \pm 0.02$ \\
Downstream & $0.0061 \pm 0.0057$ & $14.23 \pm 20.93(n=4)$ & $0.13 \pm 0.15$ \\
\hline
\end{tabular}

some higher conductivity measurements, the average was $16.3 \pm 17.2 \mathrm{~cm} \mathrm{~d}^{-1}$ (Table 3). Hydraulic conductivity measurements were relatively low, with measured rates of the order expected for silt/loess soils (see Domenico and Schwartz 1998). Such low values suggest slow hydrological exchange between the floodplain soils and river water, which is likely responsible for the poor onsite drainage and ponding of water that occurred at the downstream end of the meadow. The hydraulic conductivity of the underlying alluvial gravels on the floodplain could not be measured, but are likely to be substantially higher than the values measured in the top $2 \mathrm{~m}$ of sandy loam floodplain soil.

\section{Bankfull capacity}

Generally good agreement was obtained between the bankfull stage-discharge estimates and the Manning's equation estimates for pre- and postrestoration bankfull discharge (Table 5). Bankfull capacity of the embanked river channel using the first of these methods was predicted to be $4.53 \mathrm{~m}^{3} \mathrm{~s}^{-1}$ (Table 5 and Fig. 9). Flows above this threshold did not occur at all during the period of record of the EA gauging station (2001-2010). Similarly, the lowest of the bankfull discharge estimates using the Manning's equation $\left(4.09 \mathrm{~m}^{3} \mathrm{~s}^{-1}\right)$ was not exceeded within the discharge record, confirming that overbank flow onto the floodplain was infrequent (at least $>10$-year intervals) (Fig. 9).

Following the removal of the embankments, bankfull capacity (evaluated using the stage-discharge method) was reduced by $75 \%$ to $1.15 \mathrm{~m}^{3} \mathrm{~s}^{-1}$. River discharge exceeded this bankfull threshold during one short (1-day) high-flow event in February 2010 that averaged $1.36 \mathrm{~m}^{3} \mathrm{~s}^{-1}$ (Fig. 9). Historical river discharge data from before the restoration indicate that flows of this magnitude are fairly regular. For instance, from 2001 to 2010, river discharge was above the $1.15 \mathrm{~m}^{3} \mathrm{~s}^{-1}$ post-restoration bankfull capacity during a minimum of 14 highflow events, the majority of which (11 out of the 14 recorded) occurred during summer and autumn (Fig. 9). These were of short duration (1 day); and were typically separated by large time intervals, with the exception of a high river discharge period in May-June 2007, when successive high flows were above bankfull capacity within 10-18 days (Fig. 9). The post-restoration bankfull recurrence interval was predicted to be 0.8 years, on average (Table 5). A further indication that embankment removal will result in reconnection of the river and floodplain via over-bank flows is given in Fig. 7(c), which shows river stage in autumn 2008 above the restored bankfull elevation of $20.096 \mathrm{~m}$ (Table 5).

\section{Groundwater response to embankment removal}

After the removal of the embankments, groundwater levels at wells 3.1 and 1.1, which were located at the river-floodplain interface, generally remained higher than those within wells further from the river (Fig. 8(a) and (c)) for much of the post-removal period. This was particularly evident during the dry summer 

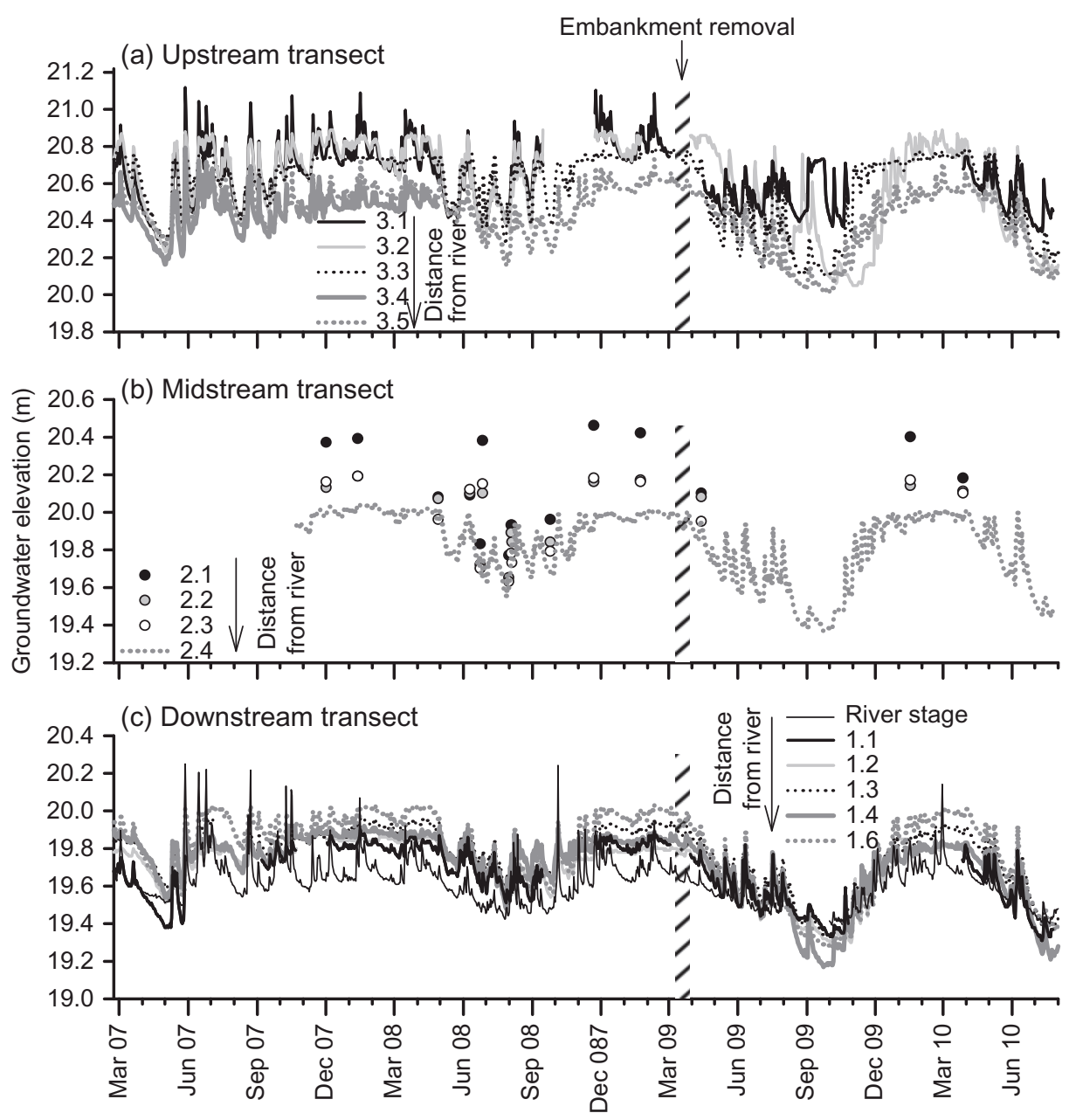

Fig. 8 Temporal variation in mean daily groundwater height above Ordnance Datum Newlyn (ODN). Well 3.1 (a) was located on the river embankment; wells 3.5 (a), 2.4 (b) and 1.6 (c) were located at the base of the hillslope (see Fig. 1). Continuous measurements of groundwater height were not available for all of the wells at the midstream transect, hence, hand measurements are also plotted (circles). River stage is plotted at the downstream transect (c).

Table 4 Soil chemistry of Hunworth Meadow along the three well transects (mean $\pm 95 \%$ confidence interval). Soils were sampled in April 2008.

\begin{tabular}{|c|c|c|c|}
\hline & Upstream transect & Midstream transect & Downstream transect \\
\hline $\mathrm{pH}$ & $6.34 \pm 0.45$ & $6.49 \pm 0.74$ & $6.51 \pm 0.13$ \\
\hline Organic matter content $(\%)$ & $12.16 \pm 2.62$ & $10.98 \pm 2.14$ & $15.38 \pm 10.37$ \\
\hline Bulk density $\left(\mathrm{g} \mathrm{m}^{-3}\right)$ & $0.71 \pm 0.07$ & $0.75 \pm 0.00$ & $0.50 \pm 0.23$ \\
\hline $\mathrm{Ca}^{2+}$ (mg g ${ }^{-1}$ dry soil) & $2.70 \pm 0.73$ & $1.87 \pm 1.08$ & $1.66 \pm 0.93$ \\
\hline $\mathrm{Na}^{+}\left(\mathrm{mg} \mathrm{g}^{-1}\right.$ dry soil $)$ & $0.12 \pm 0.09$ & $0.08 \pm 0.04$ & $0.04 \pm 0.02$ \\
\hline $\mathrm{Mg}^{+}$(mg g ${ }^{-1}$ dry soil $)$ & $0.09 \pm 0.06$ & $0.14 \pm 0.09$ & $0.10 \pm 0.07$ \\
\hline $\mathrm{K}^{+}\left(\mathrm{mg} \mathrm{g}^{-1}\right.$ dry soil $)$ & $0.96 \pm 0.39$ & $2.81 \pm 1.36$ & $1.25 \pm 1.19$ \\
\hline Total iron (mg kg-1 dry soil) & $16.50 \pm 1.91$ & $38.84 \pm 54.78$ & $66.90 \pm 69.95$ \\
\hline $\mathrm{Al}^{3+}\left(\mathrm{mg} \mathrm{kg}^{-1}\right.$ dry soil $)$ & $6.49 \pm 2.02$ & $9.99 \pm 8.94$ & $6.14 \pm 0.85$ \\
\hline $\mathrm{NH}_{4}^{+}\left(\mathrm{mg} \mathrm{N} \mathrm{kg}^{-1}\right.$ dry soil $)$ & $25.31 \pm 9.99$ & $12.81 \pm 16.48$ & $32.33 \pm 13.21$ \\
\hline $\mathrm{NO}_{3}^{-}\left(\mathrm{mg} \mathrm{N} \mathrm{kg}^{-1}\right.$ dry soil) & $2.96 \pm 3.41$ & $0.47 \pm 0.92$ & $2.22 \pm 22.36$ \\
\hline Olsen P (mg P kg-1 dry soil) & $7.12 \pm 4.97$ & $6.18 \pm 3.76$ & $9.49 \pm 3.58$ \\
\hline TOC (mg kg-1 dry soil) & $0.57 \pm 0.14$ & $0.58 \pm 0.50$ & $0.92 \pm 1.14$ \\
\hline $\mathrm{TN}(\%)$ & $0.51 \pm 0.19$ & $0.44 \pm 0.16$ & $0.58 \pm 0.44$ \\
\hline $\mathrm{TC}(\%)$ & $5.89 \pm 2.33$ & $5.56 \pm 2.38$ & $6.94 \pm 4.62$ \\
\hline
\end{tabular}


Table 5 Bankfull height above ODN, bankfull river discharge from the river stage-discharge relationship, and calculated using Manning's equation, and bankfull recurrence interval (not estimated for the prerestoration bankfull discharge due to the high uncertainty associated with extrapolating beyond the range of data).

\begin{tabular}{lllll}
\hline Transect & $\begin{array}{l}\text { Bankfull elevation } \\
\text { ODN }(\mathrm{m})\end{array}$ & \multicolumn{2}{l}{ Bankfull discharge $\left(\mathrm{m}^{3} \mathrm{~s}^{-1}\right)$} & $\begin{array}{l}\text { Bankfull recurrence } \\
\text { interval (years) }\end{array}$ \\
\cline { 3 - 4 } & & Stage-discharge & Manning's equation & \\
\hline Pre-restoration & 20.520 & 4.53 & $4.09-5.73$ & N/A \\
Post-restoration & 20.096 & 1.15 & $1.33-1.87$ & 0.83 \\
\hline
\end{tabular}

Note: ODN: Ordnance Datum Newlyn.

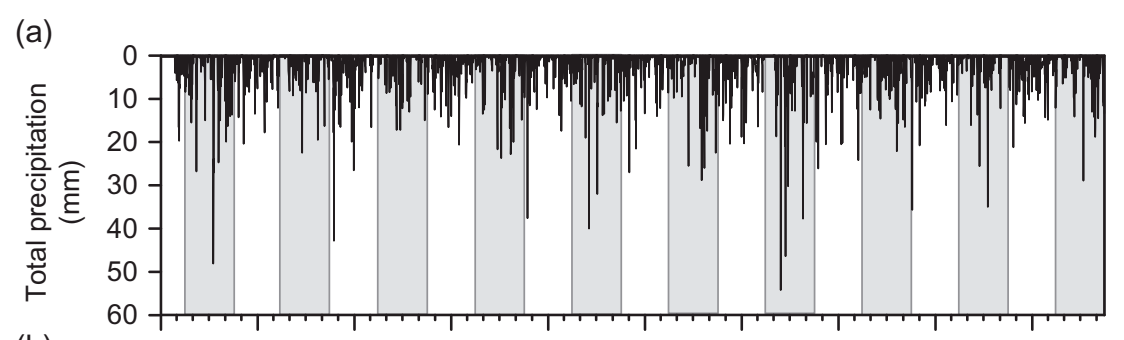

(b)

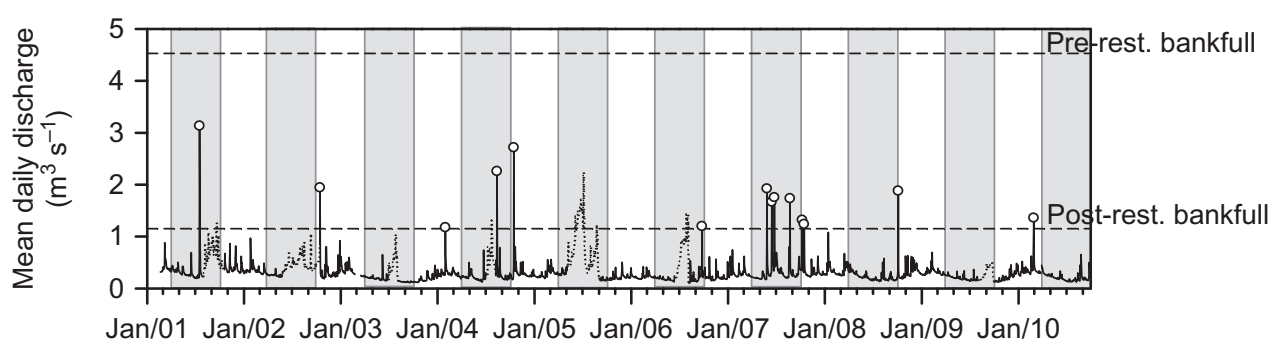

$\square$ Spring/summer $\square$ Autumn/winter 。 Post-rest. over-bank flows

Fig. 9 Time series of (a) total precipitation, and (b) mean daily river discharge from 2001 to 2010. Pre- and post-restoration bankfull capacity at the downstream river stage is shown in (b), above which inundation of the floodplain would have occurred. River discharge data affected by aquatic macrophyte growth have been highlighted with dotted lines and were not included in the analysis of bankfull discharge.

2009 (Fig. 8(a) and (c)). In contrast to the observations close to the river, water levels in all the other wells were approximately $10-60 \mathrm{~cm}$ lower during the summers following the restoration (Fig. 8(a)-(c)). Winter water table elevations remained unchanged following the restoration (Fig. 8(a)-(c)), with water levels within $10 \mathrm{~cm}$ of the soil surface in all wells. Furthermore, embankment removal lowered the soil elevation to within $0-50 \mathrm{~cm}$ of the water table at Well 3.1. This resulted in increased saturation of surface soils on the restored river banks for much of the summer in 2009 and 2010 (winter 2009 data not available), which is likely to have important effects on soil physicochemistry in this region of the floodplain.

\section{Hydrological controls on chemistry}

Groundwater (in the floodplain wells and chalk borehole) and river water cation chemistry were dominated by calcium (Table 6). Anion chemistry followed the pattern of $\mathrm{Cl}^{-}>\mathrm{SO}_{4}{ }^{-}>\mathrm{NO}_{3}{ }^{-}$. River water and regional groundwater (sampled in the chalk borehole) was slightly alkaline (mean $\mathrm{pH}$ : 7.3 and 7.4, respectively) (Table 6). In contrast, the floodplain well water was slightly acidic (mean $\mathrm{pH}$ : 6.5-6.7), potentially due to the sandy loam soil which overlays the chalk bedrock. The percentage composition of base cations in the floodplain well samples was mostly between the two main potential water sources: groundwater that was strongly dominated by calcium ions and river water that was characterised by higher levels of sodium ions (Table 4). However, differences in concentration between end members were quite small, particularly during baseflow conditions when a groundwater signature was evident in the river water. Hence, further analysis using an end-member mixing model was not considered appropriate.

Conservative solutes such as calcium, sodium and chloride, varied spatially along each well transect. However, there was no obvious pattern with distance 
Table 6 Chemistry of the River Glaven and Hunworth Meadow groundwater wells from 2007-2008 and EA borehole from 2007-2010 (mean $\pm 95 \%$ confidence interval).

\begin{tabular}{|c|c|c|c|c|c|}
\hline & River & $\begin{array}{l}\text { Transect } \\
\text { Upstream }\end{array}$ & Midstream & Downstream & EA borehole \\
\hline pH in situ & $7.3 \pm 0.5$ & $6.6 \pm 0.1$ & $6.7 \pm 0.2$ & $6.5 \pm 0.1$ & $7.4 \pm 0.2$ \\
\hline Conductivity $\left(\mu \mathrm{s} \mathrm{cm}^{-1}\right)$ & $953 \pm 213$ & $676 \pm 130$ & $775 \pm 767$ & $812 \pm 111$ & $519 \pm 50$ \\
\hline $\mathrm{Ca}^{2+}\left(\mathrm{mg} \mathrm{L}^{-1}\right)$ & $95.8 \pm 12.4$ & $113 \pm 81$ & $71.2 \pm 28.2$ & $102.6 \pm 11.5$ & $89.7 \pm 4.8$ \\
\hline $\mathrm{Na}^{+}\left(\mathrm{mg} \mathrm{L}^{-1}\right)$ & $25.6 \pm 5.1$ & $13.7 \pm 3.2$ & $24.8 \pm 10.5$ & $17.6 \pm 1.3$ & $16.1 \pm 0.2$ \\
\hline $\mathrm{Mg}^{+}\left(\mathrm{mg} \mathrm{L}^{-1}\right)$ & $5.0 \pm 0.8$ & $3.5 \pm 0.6$ & $5.2 \pm 2.2$ & $4.3 \pm 0.5$ & $5.5 \pm 0.3$ \\
\hline $\mathrm{K}^{+}\left(\mathrm{mg} \mathrm{L}^{-1}\right)$ & $2.6 \pm 0.4$ & $1.0 \pm 0.7$ & $5.5 \pm 3.0$ & $1.9 \pm 1.0$ & $1.8 \pm 0.1$ \\
\hline $\mathrm{NH}_{4}+\left(\mathrm{mg} \mathrm{N} \mathrm{L}^{-1}\right)$ & $0.6 \pm 0.1$ & $0.8 \pm 0.3$ & $0.6 \pm 0.3$ & $0.5 \pm 0.1$ & $0.0 \pm 0.0$ \\
\hline $\mathrm{Cl}^{-}\left(\mathrm{mg} \mathrm{L}^{-1}\right)$ & $45.4 \pm 1.0$ & $33.9 \pm 3.7$ & $48.6 \pm 23.0$ & $27.5 \pm 5.3$ & $31.7 \pm 2.5$ \\
\hline $\mathrm{SO}_{4}^{-}\left(\mathrm{mg} \mathrm{S} \mathrm{L}^{-1}\right)$ & $16.1 \pm 1.4$ & $10.2 \pm 4.2$ & $11.2 \pm 5.9$ & $4.8 \pm 1.5$ & $14.6 \pm 3.4$ \\
\hline $\mathrm{NO}_{3}^{-}\left(\mathrm{mg} \mathrm{N} \mathrm{L}^{-1}\right)$ & $6.2 \pm 0.5$ & $0.2 \pm 0.1$ & $0.4 \pm 0.4$ & $0.1 \pm 0.03$ & $0.2 \pm 0.0$ \\
\hline $\mathrm{TDN}\left(\mathrm{mg} \mathrm{L}^{-1}\right)$ & $5.5 \pm 4.5$ & $3.3 \pm 0.6$ & $4.7 \pm 1.4$ & $2.6 \pm 0.6$ & No data \\
\hline $\mathrm{DOC}\left(\mathrm{mg} \mathrm{L}^{-1}\right)$ & $10.8 \pm 2.3$ & $33.8 \pm 6.0$ & $46.1 \pm 7.6$ & $32.7 \pm 6.8$ & $0.8 \pm 0.2$ \\
\hline $\mathrm{DO}\left(\mathrm{mg} \mathrm{L}^{-1}\right)$ & $10.8 \pm 0.4$ & $0.4 \pm 0.2$ & $1.0 \pm 0.8$ & $0.5 \pm 0.3$ & $1.4 \pm 0.8$ \\
\hline
\end{tabular}

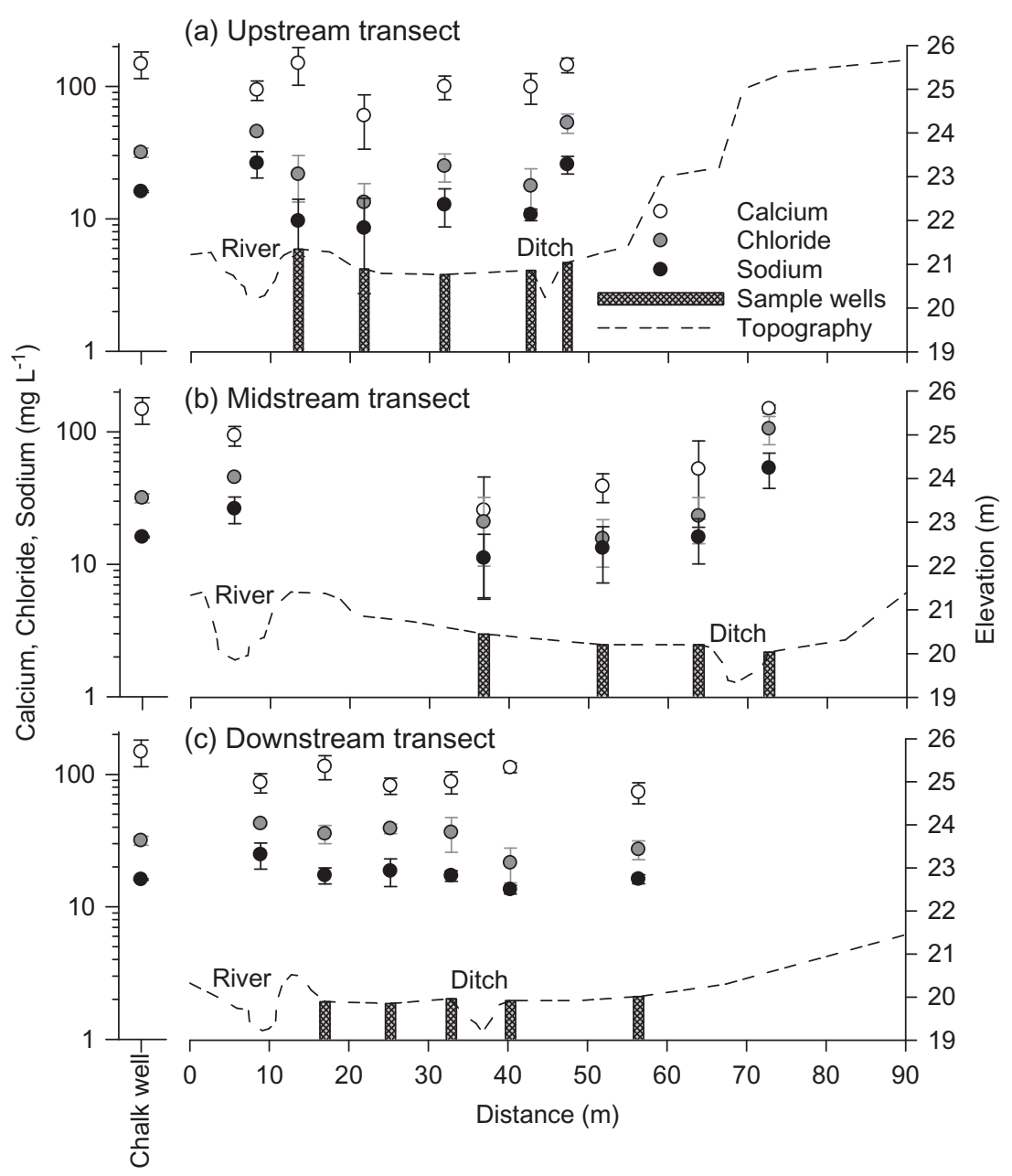

Fig. 10 Spatial variation of selected ions (mean $\pm 95 \%$ confidence interval; log scale) along subsurface flowpaths at the upstream, midstream and downstream well transects for 2007-2008. Pre-restoration topography is plotted to identify the sample locations in relation to the river and hillslope.

from the river (Fig. 10). One exception was the chemistry in wells 2.4 and 3.5 , located at the base of the woodland hillslope (Fig. 10(a) and (b)), which was markedly different from other wells on the meadow. Chloride and sodium concentrations in these two wells were, respectively, on average between 
1.7-4.2 and 1.8-3.8 times greater than average concentrations in the floodplain wells (Fig. 10(a) and (c)), which could indicate the provision of water to this part of the floodplain from hillslope throughflow. Chloride and sodium chemistry of wells located close to the river (within $10 \mathrm{~m}$ ) was closer in concentration to regional groundwater chemistry than that of the river, possibly due to limited hydrological exchange between river water and groundwater on the floodplain.

Dissolved oxygen and nitrate concentrations in river water were, respectively, approximately 18- and 14-fold greater than the concentrations in groundwater wells on the meadow $(p<0.05)$ (Fig. 11). Groundwater in these wells was consistently depleted in DO (mean: $0.6 \mathrm{mg} \mathrm{O}_{2} \mathrm{~L}^{-1}$ ) and nitrate (mean: $0.21 \mathrm{mg} \mathrm{NO}_{3}^{-}-\mathrm{N} \mathrm{L}^{-1}$ ) relative to river water (mean: $10.8 \mathrm{mg} \mathrm{O}_{2} \mathrm{~L}^{-1}$ and $6.2 \mathrm{mg} \mathrm{NO}_{3}^{-}-$ $\mathrm{N} \mathrm{L}^{-1}$, respectively) $(p<0.05)$, and exhibited little change with distance from the river. However, nitrate concentrations at Well 3.1, which was located on the embankment, showed greater variation than that of other wells on the floodplain, possibly indicating greater connectivity with river water (Fig. 11(a)). Dissolved organic carbon, in contrast, was significantly $(p<0.05)$ higher in the floodplain wells (mean at different wells between 33 and $46 \mathrm{mg} \mathrm{L}^{-1}$ ) than in river water (mean: $11 \mathrm{mg} \mathrm{L}^{-1}$ ) (Table 6), likely due to the presence of organic matter on the floodplain.

Dissolved oxygen concentration in surface soils (top 10-30 cm) was strongly coupled with water table height (Fig. 12(b) and (c)). As groundwater rose vertically through the soil profile and surface soils became saturated, DO concentration decreased
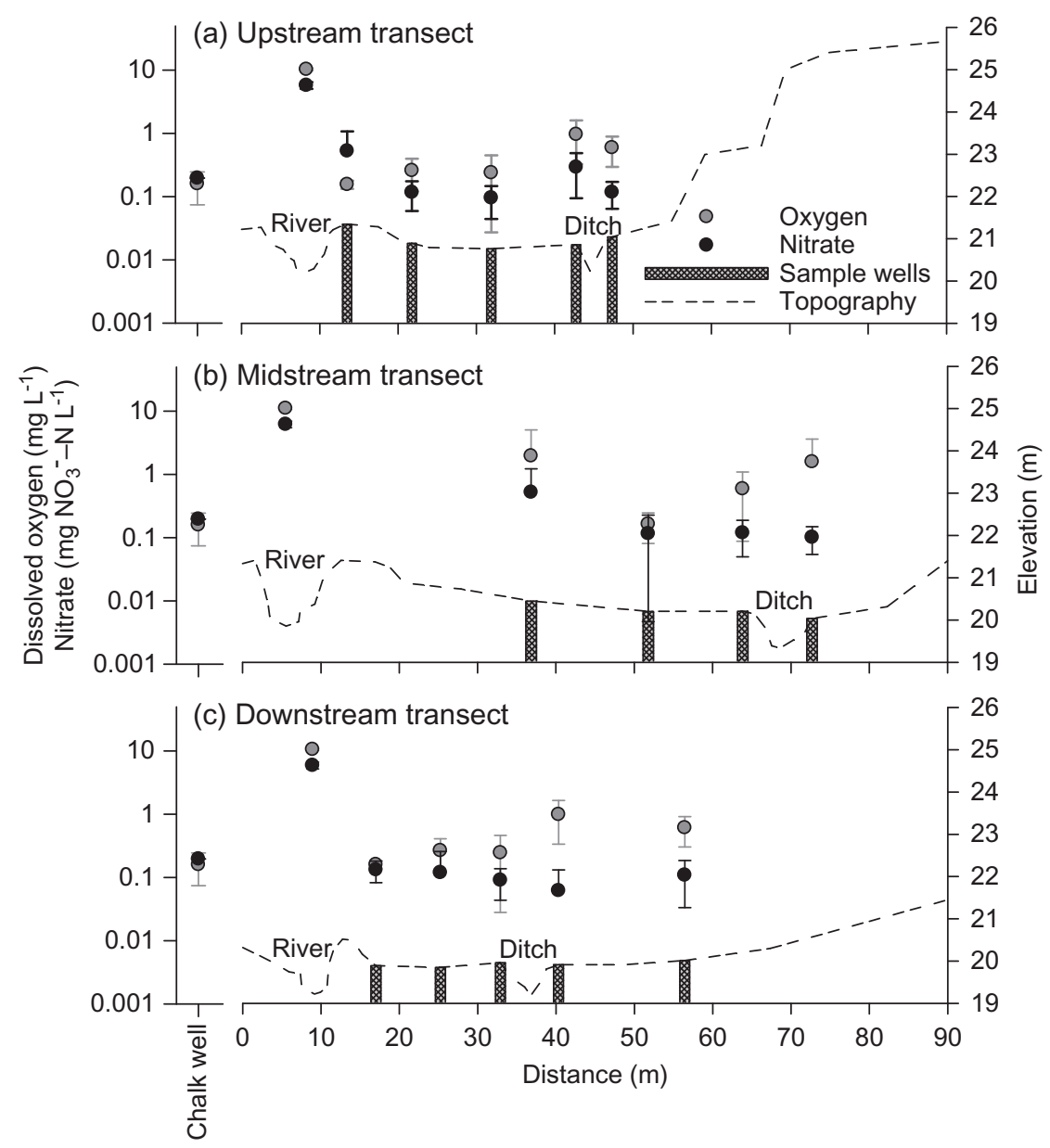

Fig. 11 Nitrate and DO concentrations (mean $\pm 95 \%$ confidence interval; log scale) in river water and groundwater along subsurface flowpaths at the upstream, midstream and downstream well transects for 2007-2008. Concentrations in the EA borehole (instrumented in the chalk) are also shown. Pre-restoration topography is plotted to identify the sample locations in relation to the river and hillslope. 
(a)

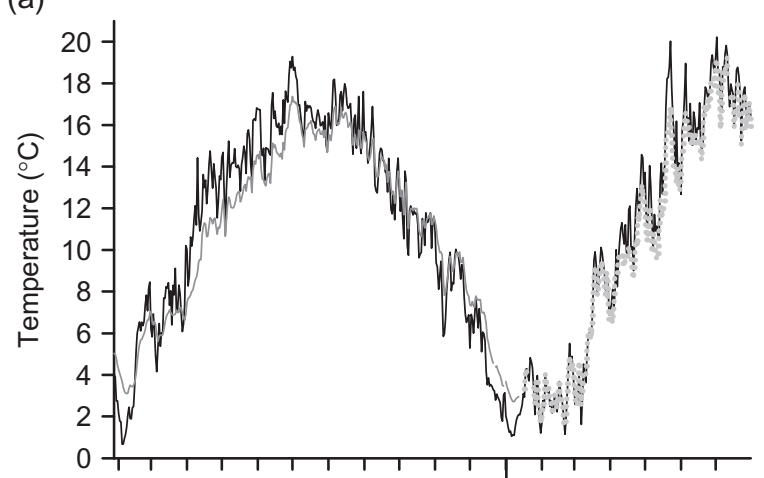

(b)

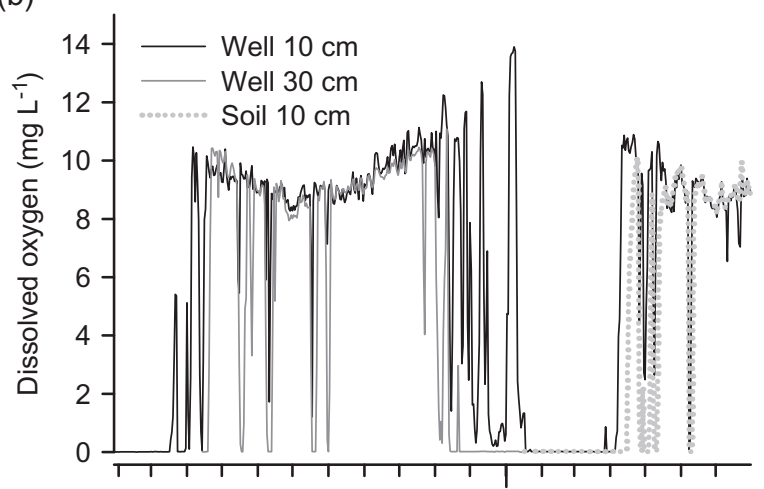

(c)

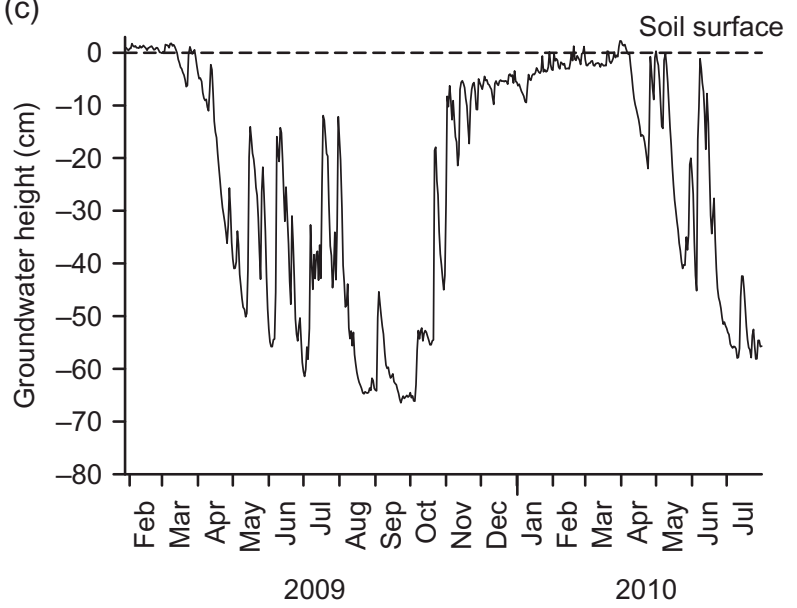

Fig. 12 Temporal variation in (a) temperature and (b) DO concentration in well water and soil in relation to (c) changes in groundwater height. When groundwater height is below the respective oxygen optode installation height (10 and $30 \mathrm{~cm}$; see text for details), optode data represent atmospheric temperature and saturated DO conditions.

rapidly within a day to $0-2 \mathrm{mg} \mathrm{L}^{-1}$, indicating reduced conditions (Fig. 12(b)). As the water table height fell once again, DO concentration increased at a rate of about $0.8-1.4 \mathrm{mg} \mathrm{L}^{-1} \mathrm{~d}^{-1}$ to atmospheric saturation (Fig. 12(b)). Groundwater DO did not increase at any point during periods of high river flow and elevated water table, suggesting that oxygen-rich river water did not inundate (via over-bank flow) the upstream area of the floodplain where the DO probes were located during the study period (Fig. 12(b)). This is further supported by site observations during high-flow events. Although Fig. 9 suggests that one over-bank flow event occurred following the embankment removal, the event was of short duration ( $\leq 1$ day) and likely only inundated the downstream, relatively lower-lying section of the floodplain.

\section{DISCUSSION}

\section{River-floodplain hydrological linkages}

As ecosystems strongly influenced by disturbances linked to flooding, floodplains are widely thought to be important for mediating the flow of water, energy, matter and organisms between aquatic and terrestrial environments (Junk et al. 1989, Tockner and Stanford 2002, Naiman et al. 2005, Mitsch and Gosselink 2007). Functioning hydrological links are key for the numerous interstitial foodwebs (see Standford and Ward 1993) and biogeochemical processes, such as aerobic respiration, nitrification, denitirification and methanogenesis, that occur in saturated sediments beneath and adjacent to rivers and streams (Jones and Holmes 1996). The reduction or absence of over-bank inundation and the associated flood-related natural disturbance regime have drastic effects on biological and chemical conditions on floodplains. For example, over-bank flooding is important for the deposition of nutrients and sediments, the control of dominant plant species and the transport of propagules, which leads to increased species richness and flood-water storage (Brunet et al. 1994, Ward and Stanford 1995, Silvertown et al. 1999, Bullock and Acreman 2003, Nilsson et al. 2010).

The embankments along the River Glaven represented a substantial barrier to river-floodplain interactions. Without over-bank flow, slow horizontal subsurface flow $\left(<0.4 \mathrm{~cm} \mathrm{~d}^{-1}\right)$ was the primary mechanism for the exchange of water, DO and nutrients between the river and floodplain. With such low-flow velocities, it would take approximately 1 year for a molecule of water to travel a distance of $1.5 \mathrm{~m}$ from the river towards the floodplain. During high river flows, when river stage was above groundwater elevation on the floodplain, there was a greater potential for lateral subsurface mixing of river and groundwater. However, considering the low subsurface flow rates, groundwater movement on the floodplain is likely to be dominated by the rapid ( $<1$ day) vertical transfer of deeper 
nitrate-depleted groundwater through the soil profile that was observed in response to precipitation. This prompt groundwater response to precipitation input, despite low hydraulic conductivity, is a phenomenon that has been reported in many small catchments and is not well understood (Kirchner 2003, Cloke et al. 2006).

A similar study on a chalk river in the Berkshire Downs, UK, found that the majority of surfacesubsurface hydrological exchange occurred a few tens of centimetres from the river bed, and was limited to within the gravel aquifer. The underlying chalk at the site was found to be hydraulically separate from the river (Allen et al. 2010). Throughout the River Glaven catchment, a chalk-rich boulder clay (Lowestoft Formation) underlies the alluvium and gravels (Moorlock et al. 2002); this formation is reported to be variably permeable, containing groundwater only when weathered, fractured or interspersed with sand and gravel horizons (BGS 2007). The presence of this less permeable layer at the site could restrict hydrological contact between the river and chalk bedrock. However, the chemical similarity between the floodplain wells and chalk well samples, and the high baseflow index and flow exceedence values for Q95, indicate substantial interaction with the chalk aquifer.

The alluvial and glaciogenic gravels that overlie the Lowestoft Formation are likely to have substantially higher hydraulic conductivity than the overlying alluvium. While this could provide a route for more substantial mixing between river and groundwater at depth, conservative ion chemistry in the wells has a groundwater signature. The higher nitrate concentration measured in Well 3.1, which is located next to the river, suggests some connectivity between the river and groundwater on the floodplain. In general though, there was a lack of spatial and temporal variation in the conservative ion chemistry of well water across the floodplain, indicating that even in a chalk setting there are regions of limited hyporheic extent. Over-bank inundation therefore represents the only potential mechanism for substantial surface water-groundwater connectivity.

Soils at Hunworth Meadow were of intermediate fertility (i.e. within the range of $5-15 \mathrm{mg} \mathrm{kg}^{-1}$ Olsen extractable phosphorus specified by Gowing et al. 2002a), likely due to the cessation of fertilizer application at the site in 1997 and the absence of floodwater and river sediment inputs. Water flowing within the River Glaven is substantially richer in nitrate and DO relative to floodplain groundwater, and thus represents a potential source of nutrients to floodplain vegetation and microbes. The large difference in nitrate and DO concentrations between river water and groundwater $<2 \mathrm{~m}$ away from the channel indicate that a strong redox gradient is present at the river-floodplain interface. This part of the floodplain is likely to be an important zone for reducing nitrate concentrations (e.g. Dahm et al. 1998, Hedin et al. 1998, Clilverd et al. 2008).

Continuous measurements of DO concentration in floodplain soils, which to our knowledge have not been measured using DO optodes before, indicate a strong coupling between water-table fluctuations and anoxia in the rooting zone. Surface soils were anoxic for much of the winter, and periodically during wetter periods through the summer that were associated with high precipitation during within-bank high-flow events, implying reducing conditions for nitrate and other redox-sensitive solutes. Episodic inundation of the floodplain with nitrate-rich river water could likely serve as a pulse of nitrate to anaerobic microbes, leading to greater potential for nitrate removal via denitrification (see Fisher and Acreman 2004). Furthermore, during high river discharge on the River Glaven, groundwater flows through an organic topsoil. These conditions can result in the intersection of nitrate-rich river water with soil water that is rich in DOC, which often promotes further substantial denitrification (e.g. Hedin et al. 1998, Hill et al. 2000).

The removal of the river embankments at the study site sufficiently reduced the channel crosssectional area, and thus bankfull capacity, to initiate over-bank inundation and reconnect the river with its floodplain. One over-bank event was observed during the period of study, and long-term river discharge data from before the restoration indicate that river flows will regularly exceed the restored bankfull capacity. Flood events will be of short duration, as bank-full capacity was typically exceeded for only one day, and they will often occur during the summer months when surface soils are dry and have a greater capacity for water storage, which is likely to maximise floodpeak attenuation (e.g. Burt et al. 2002). Flooding may also persist for even longer periods, depending on the infiltration and evapotranspiration rates, and the influence of in-river macrophyte growth during the summer. Increased frequency and duration of floodplain inundation due to embankment removal is consistent with other river restoration studies (e.g. Acreman et al. 2003, Helfield et al. 2007, Hammersmark et al. 2008) and is seen as one of the main aims of river restoration projects. 
So far, an increase in the frequency of overbank flooding is suggested to be the most dramatic hydrological effect following the restoration of the floodplain. Increased groundwater levels at the riverfloodplain interface have also been observed, possibly due to enhanced river water intrusion. The most noticeable change in soil saturation in this region of the floodplain, however, was due to a lowering of the surface elevation relative to the water table height. This occurred along a 1-2 m strip where the embankments were previously located, and is likely to promote re-colonisation by wetland plant species that can tolerate periodic waterlogging and aeration stress in the rooting zone, particularly during the growing season (e.g. Silvertown et al. 1999, Barber et al. 2004, Wheeler et al. 2004). However, water levels in the rest of the floodplain were lower during the summers following the restoration. This could be a result of the prevailing low summer precipitation and high evapotranspiration rates in these years. The areal extent of inundation on the floodplain could potentially be far-reaching due to the lowlying elevation of the meadow in relation to the river; however, further analysis including the continuation of hydrological monitoring and the application of hydrological/hydraulic modelling (e.g. Thompson et al. 2004) is required to determine flood inundation extents for a range of flows.

\section{Floodplain ecohydrology}

Prior to embankment removal, Hunworth Meadows comprised a degraded Holcus lanatus-Juncus effusus rush pasture community (Clilverd et al. 2009). This is classified as MG10 under the UK National Vegetation Communities system (Rodwell 1998), which is typically associated with waterlogged soils. This is congruent with the prolonged saturation of surface soils observed pre-restoration during winter and spring, and with the periodic saturation occurring during summer and autumn months, all of which occurred during within-bank river flows. Flooding, particularly during the growing season, can cause aeration stress in plants, with prolonged waterlogging leading to species-poor plant communities (Jackson and Colmer 2005). This stands in stark contrast to the effects related to low-intensity summer flooding of the floodplain with river water, which is predicted for the site following the removal of the embankments along the River Glaven. Recurrent over-bank inundation increases environmental heterogeneity and is believed to have a positive effect on floodplain plant diversity, firstly by limiting competition by dominant plant species (e.g. Silvertown et al. 1999, Helfield et al. 2007), and secondly by opening new patches for colonization by hydrochorically deposited propagules (e.g. Auble and Scott 1998, Nilsson et al. 2010).

In contrast to brief summer inundation events, infrequent floods of lengthy duration during the growing season can negatively affect floodplain diversity, either by burying plants with river sediment, or by exceeding tolerance limits for anoxia in the rooting zone of sensitive species (e.g. Gowing and Youngs 1997, Friedman and Auble 1999); however, floods of this type were not observed during the 10 years of river discharge data available. Furthermore, at Hunworth Meadow there is initial evidence to suggest that reconnection will improve drainage and create drier conditions between flood events due to the easier drainage of the floodplain following the removal of the embankments, which partly moderates the effects of large floods.

Re-establishment of over-bank flooding may result in nutrient enrichment of floodplain soils from flood-deposited sediment and nutrient-rich river water (Gowing et al. 2002b). While this may function to protect adjacent ecosystems from nutrient loading, increased nutrient supply may pose a risk to plant species richness at the restoration site (Vermeer and Berendse 1983, Verhoeven et al. 1996, Janssens et al. 1998, Michalcová et al. 2011) and over-ride the ecological benefits of improved river-floodplain connections. In such instances, further management may be required. In the case of Hunworth Meadow, which is a mesotrophic wet grassland, the additional supply of nutrients could be managed with traditional hay cutting. This would help balance the input of riverderived nutrients to the floodplain with the removal of nutrients in plant biomass (Linusson et al. 1998, Wheeler et al. 2004).

In addition to the embankment removal, a second-phase in-stream restoration project was conducted on the same stretch of river in August 2010, one year after the embankment removal and after the main period of fieldwork reported in this study. This involved the creation of a new, narrower and more geomorphically diverse, meandering river channel. Continued monitoring of hydrological conditions on the floodplain alongside regular vegetation surveys (e.g. Clilverd et al. 2009) will be used to evaluate changes in hydrological regime following the two differing stages of restoration, and the long-term effects on plant community composition. 


\section{CONCLUSIONS}

Inter-annual climate variability complicates direct comparisons of pre- and post-restoration hydrological conditions. In this study, the two cool and wet spring/summer periods observed prior to the restoration, and the significantly warmer and drier spring/summers after the restoration, render it difficult to clearly determine the effects that embankment removal had on the floodplain soil-water regime-possibly with the exception of the nearriver environment. This highlights the potential of hydrological/hydraulic modelling (underway for Hunworth Meadow) to simulate floodplain hydrology before and after restoration but under identical climatic conditions (e.g. Hammersmark et al. 2008).

Prior to the restoration, the river and floodplain were linked primarily via slow subsurface flowpaths, with the soil water regime on the floodplain being controlled by anoxic, nutrient-poor groundwater. Removal of river embankments has re-established over-bank flow, providing opportunities for regular bidirectional surface-subsurface flow and, consequently, the floodplain is likely to shift to a more disturbance-based environment controlled by oxygen-rich river water as well as groundwater. Restoration of river-floodplain connectivity is likely to cause more frequent, short-duration inundation of the floodplain, resulting in improved flood storage and a more favourable soil-water regime that may enhance floodplain plant diversity. Furthermore, regular over-bank flow and supply of nutrient-rich river water to the floodplain during the summer months, when microbial and plant activity is high, will favour conditions for removal of nutrients from the river.

Acknowledgements Funding and support was provided by the Environment Agency, UCL Geography Department, University of London Central Research Fund Grant, and UCL Graduate School. We thank Ross Haddow and Adel MacNicol of the Stody Estate for their encouragement, Richard Hey for designing the river restoration, and the River Glaven Conservation Group, Environment Agency, Wild Trout Trust and Natural England for their technical support during the embankment removal. Many thanks to Queen Mary University of London for providing the field equipment, and a special thanks to Derek Sayer, Chabungbam Rajagopal Singh, Victoria Sheppard and Helene Burningham for their assistance in the field, and Simon Dobinson, Laura Shotbolt, and Ian Patmore for their assistance in the laboratory.

\section{REFERENCES}

Aanderaa, 2006. TD 218 Operating manual oxygen optode 3830, 3835, 3930, 3975, 4130, 4175 [online]. Bergen, Aanderaa Data Instruments. http://www.aadi.no [Accessed 15 August 2010].

Acreman, M.C., Riddington, R., and Booker, D. J., 2003. Hydrological impacts of floodplain restoration: a case study of the River Cherwell, UK. Hydrology and Earth System Sciences, 7 (1), 75-86.

Acreman, M.C., et al., 2007. Hydrological science and wetland restoration: some case studies from Europe. Hydrology and Earth System Sciences, 11 (1), 158-169.

Allen, D.J., et al., 2010. Interaction between groundwater, the hyporheic zone and a Chalk stream: a case study from the River Lambourn, UK. Hydrogeology Journal, 18 (5), 1125-1141.

Allen, R.G., 2000. Using the FAO-56 dual crop coefficient method over an irrigated region as part of an evapotranspiration intercomparison study. Journal of Hydrology, 229 (1-2), $27-41$.

Antheunisse, A.M., et al., 2006. Regional differences in nutrient limitation in floodplains of selected European rivers. River Research and Applications, 22, 1039-1055.

Auble, G.T. and Scott, M.L., 1998. Fluvial disturbance patches and cottonwood recruitment along the upper Missouri River, Montana. Wetlands, 18 (4), 546-556.

Baird, A.J., Surridge, B.W.J., and Money, R.P., 2004. An assessment of the piezometer method for measuring the hydraulic conductivity of a Cladium mariscus - Phragmites australis root mat in a Norfolk (UK) fen. Hydrological Processes, 18, 275-291.

Baker, M.A., and Vervier P., 2004. Hydrological variability, organic matter supply and denitrification in the Garonne River ecosystem. Freshwater Biology, 49 (2), 181-190.

Barber, K.R., et al., 2004. Soil aeration status in a lowland wet grassland. Hydrological Processes, 18 (2), 329-34.

Bernhardt, E.S., et al., 2005. Synthesizing U.S. river restoration efforts. Science, 308 (5722), 636-637.

Berrie, A.D., 1992. The chalk-stream environment. Hydrobiologia, 248 (1), 3-9.

BGS (British Geological Survey), 2007. Geological assessmentdetailed. Georeports GR_109305_1 [online]. Keyworth: British Geological Survey. Available from: http://www.great-yarmouth. gov.uk/appendix-11.2-2007-bgs-detailed-report.pdf [Accessed 27 July 2011].

Billy, C., et al., 2010. Nitrogen isotopic composition of leached nitrate and soil organic matter as an indicator of denitrification in a sloping drained agricultural plot and adjacent uncultivated riparian buffer strips. Soil Biology and Biochemistry, 42 (1), 108-117.

Boulton, A.J., et al., 1998. The functional significance of the hyporheic zone in streams and rivers. Annual Review of Ecological Systems, 29, 59-81.

Brand, E.W. and Premchitt, J., 1980. Shape factors of cylindrical piezometers. Géotechnique 30, 369-384.

British Atmospheric Data Centre, 2010. Met Office-MIDAS land surface station data [online]. Didcot: The NCAS British Atmospheric Data Centre. Available from: http://badc.nerc.ac. uk [Accessed 1 September 2010].

Brunet, R.C., et al., 1994. Role of the floodplain and riparian zone in suspended matter and nitrogen retention in the Adour River, south-west France. River Research and Applications, 9 (1), $55-63$.

Buijse, A.D., et al., 2002. Restoration strategies for river floodplains along large lowland rivers in Europe. Freshwater Biology, 47 (4), 889-907.

Bullock, A., and Acreman, M.C., 2003. The role of wetlands in the hydrological cycle. Hydrology and Earth System Sciences, 7 (3), $75-86$. 
Burt, T.P., et al., 1999. Denitrification in the riparian buffer zone: the role of floodplain sediments. Hydrological Processes, 13 (10), $1451-1463$.

Burt, T.P., et al., 2002. Water table fluctuations within the floodplain of the River Severn, England, Journal of Hydrology, 262, 1-20.

Chambers, P.A., et al., 1991. Current velocity and its effect on aquatic macrophytes in flowing waters. Ecological Applications, 1 (3): 249-257.

Champion, P.D. and Tanner, C.C., 2000. Seasonality of macrophytes and interaction with flow in a New Zealand lowland stream. Hydrobiologia, 441 (1), 1-12.

Chappell, A., 1998. Dispersing sandy soil for the measurement of particle size distributions using optical laser diffraction. Catena, 31 (4), 271-281.

Clarke, S.J., 2002. Vegetation growth in rivers: influences upon sediment and nutrient dynamics. Progress in Physical Geography, $26(2), 159-172$.

Clilverd, H.M., Jones, J.B. Jr, and Kielland, K., 2008. Nitrogen retention in the hyporheic zone of a glacial river in interior Alaska. Biogeochemistry, 88 (1), 31-46.

Clilverd, H.M., et al., 2009. Hydrological restoration of riverfloodplain connections and the effects on wet grassland plant communities. Poster presented at Hydro-Eco'2009, Vienna, April.

Cloke, H.L., et al., 2006. Using numerical modelling to evaluate the capillary fringe groundwater ridging hypothesis of streamflow generation. Journal of Hydrology, 316, 141-162.

Cunderlik, J.M. and Burn, DH., 2001. The use of flood regime information in regional flood frequency analysis. Hydrological Sciences Journal, 47 (1), 77-92.

Dahm, C.N., et al., 1998. Nutrient dynamics at the interface between surface waters and groundwaters. Freshwater Biology, 40 (3), 427-451.

DeLaney, T.A., 1995. Benefits to downstream flood attenuation and water quality as a result of constructed wetlands in agricultural landscapes. Journal of Soil and Water Conservation, 50 (6), 620-626.

de Smith, M.J., Goodchild, M.F., and Longley, P.A., 2007. Geospatial Analysis - a comprehensive guide to principles techniques and software tools. Leicester: Troubador.

Dingman, S.L., 1994. Physical hydrology. Englewood Cliffs, NJ: Prentice Hall, 325-327.

Domenico, P. A. and Schwartz, F.W., 1998. Physical and chemical hydrogeology. 2nd ed. Chichester: John Wiley and Sons.

Elliot, E.T., et al., 1999. Soil structural and other physical properties. In: G.P. Robertson, et al., eds. Standard soil methods for long-term ecological research. Oxford: Oxford University Press, 73-78.

Fisher, J. and Acreman, M. C. 2004. Wetland nutrient removal: a review of the evidence. Hydrology and Earth System Sciences, 8 (4), 673-685.

Forshay, K.J. and Stanley, E. 2005. Rapid nitrate loss and denitrification in a temperate river floodplain. Biogeochemistry, 75, 43-64.

Freeman, M.C., Pringle, C.M., and Jackson, C.R., 2007. Hydrologic connectivity and the contribution of stream headwaters to ecological integrity at regional scales. Journal of the American Water Resources Association, 43 (1), 5-14.

Friedman, J.M. and Auble, G.T., 1999. Mortality of riparian box elder from sediment mobilization and extended inundation. Regulated Rivers: Research and Management, 15 (5), 463-476.

Gordon, N.D., McMahon, T.A., and Finlayson, B.L., 2004. Stream hydrology: An introduction for ecologists. Chichester: John Wiley and Sons.

Gowing, D.J.G. and Youngs, E.G., 1997. The effect of the hydrology of a Thames flood meadow on its vegetation pattern. British Hydrological Society Occasional Paper, 8, 69-80.
Gowing, D.J.G., et al., 2002a. A review of the ecology, hydrology and nutrient dynamics of floodplain meadows in England. Peterborough: English Nature, Research Report no. 446.

Gowing, D.J.G., et al., 2002b. The water regime requirements and the response to hydrological change of grassland plant communities. Bedford: Institute of Water and Environment, DEFRA Report BD1310.

Gregory, S.V., et al., 1991. An ecosystem perspective of riparian zones. Bioscience, 41, 540-551.

Grevilliot, F., Krebs, L., and Muller, S., 1998. Comparative importance and interference of hydrological conditions and soil nutrient gradients in floristic biodiversity in flood meadows. Biodiversity and Conservation, 7 (11), 1495-1520.

Gustard, A., Bullock, A., and Dixon, J.M., 1992. Low flow estimation in the United Kingdom. Wallingford: Institute of Hydrology, Report no. 108, 20-25.

Hammersmark, C.T., Cable Rains, M., and Mount, J.F. 2008. Quantifying the hydrological effects of stream restoration in a montane meadow, Northern California, USA. River Research and Applications, 24 (6), 735-753.

Hedin, L.O., et al., 1998. Thermodynamic constraints on nitrogen transformations and other biogeochemical processes at soil-stream interfaces. Ecology, 79 (2), 684-703.

Heiri, O., Lotter, A.F., and Lemcke, G., 2001. Loss on ignition as a method for estimating organic and carbonate content in sediments: reproducibility and comparability of results. Journal of Paleolimnology, 25, 101-110.

Helfield, J.M., et al., 2007. Restoration of rivers used for timber floating: effects on riparian plant diversity. Ecological Applications, $17,840-851$

Hendershot, W.H., et al., 2008. Exchangeable cations and total exchange capacity by the ammonium acetate method at $\mathrm{pH} 7.0$ (Lavkulich 1981). In: M.R. Carter and E.G. Gregorich, eds. Soil sampling and methods of analysis, 2nd ed. edition, Boca Raton, FL: CRC Press, 203-206.

Hill, A.R., 2000. Stream chemistry and riparian zones. In: J.B. Jones and P.J. Mulholland, eds. Streams and groundwaters. London: Academic Press, 83-110.

Hill, A.R., et al., 2000. Subsurface denitrification in a forest riparian zone: interactions between hydrology and supplies of nitrate and organic carbon. Biogeochemistry, 51, 193-223.

Hough, M.N. and Jones, R.J.A., 1997. The United Kingdom Meteorological Office Rainfall and Evaporation Calculation System: MORECS version 2.0-an overview. Hydrology and Earth System Sciences, 1 (2), 227-239.

Hvorslev, M.J., 1951. Time lag and soil permeability in groundwater observations. Mississippi: United States Army Corps of Engineers, Waterways Experimental Station Bulletin 36, 50.

Institute of Hydrology, 1980. Low flow studies report. Wallingford: Institute of Hydrology.

Institute of Hydrology, 1999. Flood estimation handbook, 3: Statistical procedures for flood frequency estimation. Wallingford: Institute of Hydrology.

Jacklin, T., Johnson, S., and Twiddy, E., 2010. A catalyst for trout habitat improvement: a review of the wild trout trust advisory visit programme. In: P. Kemp, ed. Salmonid fisheries: freshwater habitat management. Chichester: Wiley-Blackwell, 293.

Jackson, M. B. and Colmer, T.D., 2005. Response and adaptation by plants to flooding stress. Annals of Botany, 96 (4), 501-505.

Janssens, F., et al., 1998. Relationship between soil chemical factors and grassland diversity. Plant and Soil, 202 (1), 69-78.

Jones, J.B. Jr and Holmes, R.M., 1996. Surface-subsurface interactions in stream ecosystems. Trends in Ecology and Evolution, $11(6), 239-242$.

Junk, W.J., Bayley, P.B., and Sparks, R.E., 1989. The flood pulse concept in river floodplain systems. In: D.P. Dodge, ed. Proceedings of the international large river symposium. Canadian 
Special Publications in Fisheries and Aquatic Science 106, $110-127$.

Kirchner, J.W., 2003. A double paradox in catchment hydrology and geochemistry. Hydrological Processes, 17, 871-874.

Leyer, I., 2005. Predicting plant species' responses to river regulation: the role of water level fluctuations. Journal of Applied Ecology, 42, 239-250.

Linusson, A.-C., Berlin, G.A.I., and Olsson, E.G.A., 1998. Reduced community diversity in semi-natural meadows in southern Sweden, 1965-1990. Plant Ecology, 136 (1), 77-94.

Marsh, T.J. and Hannaford J., eds., 2008. UK Hydrometric register. Wallingford: Centre for Ecology and Hydrology, 7.

Michalcová, D., et al., 2011. The combined effect of waterlogging, extractable $\mathrm{P}$ and soil $\mathrm{pH}$ on $\alpha$-diversity: a case study on mesotrophic grasslands in the UK. Plant Ecology, 212 (5), 879-888.

Mitsch, W.J. and Gosselink, J.G. 2007. Wetlands. 4th ed. New York: John Wiley \& Sons.

Monteith, J.L., 1965. Evaporation and the environment. Symposia of the Society for Experimental Biology, 19, 205-234.

Moorlock, B.S.P., et al., 2002. Geology of the Cromer District-a brief explanation of the geological map. Sheet Explanations of the British Geological Survey. 1:50 000 Sheet 131 Cromer (England and Wales). Keyworth: BGS, 25-26.

Muhar, S., Schmutz, S., and Jungwirth, M. 1995. River restoration concepts - goals and perspectives. Hydrobiologia, 303 (1-3), 183-194.

Naiman, R.J., Decamps, H., and McClain, M.E., 2005. Riparia: ecology conservation and management of streamside communities. London: Elsevier Academic Press, 12-14.

Nilsson, C., et al., 2010. The role of hydrochory in structuring riparian and wetland vegetation. Biological Reviews, 85 (4), 837-858.

Olsen, S.R., et al., 1954. Estimation of available phosphorus in soils by extraction with sodium bicarbonate. Washington, DC: US Government Print Office, US Department of Agriculture Circular 939.

Pawley, S.M., 2008. The Glaven Valley (Glandford Quarry) (TG 055415). In: I. Candy, R. Lee, and A.M. Harrison, eds. The Quaternary of northern East Anglia. Devon: Quaternaty Research Association, 192-203.

Poff, N.L., et al., 1997. The natural flow regime: a paradigm for river conservation and restoration. BioScience, 47 (11), 769-784.

Pringle, C.M., 2003. What is hydrologic connectivity and why is it ecologically important? Hydrological Processes, 17 (13), 2685-2689.

Robertson, A.I., Bacon, P., and Heagney, G., 2001. The responses of floodplain primary production to flood frequency and timing. Journal of Applied Ecology, 38, 126-136.

Robertson, G.P., et al., 1999. Exchangeable ions, pH, and cation exchange capacity. In: G.P. Robertson, et al., eds. Standard soil methods for long-term ecological research. Oxford: Oxford University Press, 106-109.

Rodwell, J.S., 1998. British plant communities. Volume 3Grasslands and montane communities. Cambridge: Cambridge University Press.

Rosgen, D.L., 1996. Applied river morphology. Fort Collins, CO: Wildland Hydrology.

Rosgen, D.L., 2007. Rosgen geomorphic channel design. In: J. Bernard, J.F. Fripp, and K.R. Robinson, eds. Part 654 stream restoration design national engineering handbook (210-VI$N E H)$. Washington, DC: US Department of Agriculture Natural Resources Conservation Service, 15.

Schade, J.D., et al., 2002. Sources of nitrogen to the riparian zone of a desert stream: implications for riparian vegetation and nitrogen retention. Ecosystems, 5, 68-79.

Schoenau, J.J. and O'Halloran, I. P., 2008. Sodium bicarbonateextractable phosphorus. In: M.R. Carter and E.G. Gregorich, eds. Soil sampling and methods of analysis, 2nd ed. Boca Raton, FL: CRC Press, 89-94.

Sear, D.A., Armitage, P.D., and Dawson, F.H., 1999. Groundwater dominated rivers. Hydrological Processes, 13, 255-276.

Silvertown, J., et al., 1999. Hydrologically defined niches reveal a basis for species richness in plant communities. Nature, 400, 61-63.

Surridge, B.W.J., Baird, A.J., and Heathwaite, A.L., 2005. Evaluating the quality of hydraulic conductivity estimates from piezometer slug tests in peat. Hydrological Processes, 19 (6), $1227-1244$.

Thompson, J.R., et al., 2004. Application of the coupled MIKE SHE/MIKE 11 modelling system to a lowland wet grassland in Southeast England. Journal of Hydrology, 293 (1-4), 151-179.

Tockner, K., et al., 1999. Hydrological connectivity, and the exchange of organic matter and nutrients in a dynamic riverfloodplain system (Danube, Austria). Freshwater Biology, 41 (3), 521-535.

Tockner, K. and Stanford, J.A., 2002. Riverine flood plains: present state and future trends. Environmental Conservation, 29 (3), 308-330.

Triska, F.J., et al., 1989. Retention and transport of nutrients in a thirdorder stream in northwestern California: hyporheic processes. Ecology, 70, 1893-1905.

Triska, F.J., Duff, J.H., and Avanzino, R.J., 1993. The role of water exchange between a stream channel and its hyporheic zone in nitrogen cycling at the terrestrial-aquatic interface. Hydrobiologia, 251 (1-3), 167-184.

Venterink, H.O., Hummelink, E., and Van Den Hoorn, M.W., 2003. Denitrification potential of a river floodplain during flooding with nitrate-rich water: grasslands versus reedbeds. Biogeochemistry, 65 (2), 233-244.

Verhoeven, J.T.A., Koerselman, W., and Meuleman, A.F.M., 1996. Nitrogen- or phosphorus-limited growth in herbaceous, wet vegetation: relations with atmospheric inputs and management regimes. Trends in Ecology \& Evolution, 11 (12), 494- 497.

Vermeer, J.G. and Berendse, F., 1983. The relationship between nutrient availability, shoot biomass and species richness in grassland and wetland communities. Plant Ecology, 53 (2), 121-126.

Vidon, P. and Hill, A.R., 2004. Denitrification and patterns of electron donors and acceptors in eight riparian zones with contrasting hydrogeology. Biogeochemistry, 71 (2), 259-283.

Wahl, T.L. and Wahl, K.L., 2007. A computer program for determining an index to base flow [online]. Lakewood, CO: US Department of the Interior. Available from: http://www.usbr. gov/pmts/hydraulics_lab/twahl/bfi/ [Accessed 9 June 2011].

Ward, J.V., 1998. Riverine landscapes: biodiversity patterns, disturbance regimes, and aquatic conservation. Biological Conservation, 83 (3), 269-278.

Ward, J.V. and Stanford, J.A., 1995. Ecological connectivity in alluvial river ecosystems and its disruption by flow regulation. Regulated Rivers: Research and Management, 11 (1), 105-119.

Wheeler, B.D., et al., 2004. Ecohydrological guidelines for lowland wetland plant communities. Peterborough: Environment Agency, Final Report.

Wilcock, R.J., et al., 1999. The influence of aquatic macrophytes on the hydraulic and physico-chemical properties of a New Zealand lowland stream. Hydrobiologia, 416, 203-214.

Woodcock, B.A., et al., 2005. Re-creation of a lowland flood-plain meadow: management implications for invertebrate communities. Journal of Insect Conservation, 9 (3), 207-218.

Wyżga, B., 2001. Impact of the channelization-induced incision of the Skawa and Wisłoka Rivers, southern Poland, on the conditions of overbank deposition. Regulated Rivers: Research and Management, 17 (1), 85-100. 